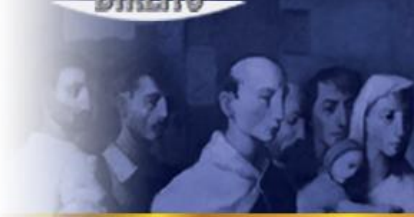

Cadernos do Programa de Pós-Graduação volume $10 \mid$ n. 2| 2015/seer.utrgs.br/ppgdir

\title{
IMPLEMENTAÇÃO DO PROCESSO ELETRÔNICO NA JUSTIÇA ESTADUAL NO RIO GRANDE DO SUL: UMA POLÍTICA PÚBLICA PARA GARANTIR A RAZOÁVEL DURAÇÃO DO PROCESSO
}

\author{
IMPLEMENTATION OF THE ELECTRONIC PROCEEDINGS IN THE STATE JUSTICE OF \\ RIO GRANDE DO SUL: A PUBLIC POLICY TO ENSURE THE REASONABLE LENGTH OF \\ PROCEEDINGS
}

\author{
Angelica Denise Klein* \\ Fabiana Marion Spengler**
}

\begin{abstract}
RESUMO: O acesso à justiça e a busca pela razoável duração processual são princípios que primam pela efetiva prestação jurisdicional. A inserção do inciso LXXVIII no elenco de direitos e garantias individuais (artigo $5^{\circ}, \mathrm{CFB}$ ) visou, desde o início, a assegurar a razoável duração dos processos, tanto na via administrativa quanto judicial. A partir de então, o Poder Judiciário inseriu alguns sistemas, dentre eles, a informatização do processo judicial, adotando-se procedimentos burocráticos mais céleres, econômicos e eficientes. Assim, a pesquisa versará sobre a análise do processo eletrônico no âmbito da justiça estadual do Rio Grande do Sul como possibilidade de assegurar a razoável duração do processo. Nesse sentido, o problema incide em verificar se a implementação do processo eletrônico no âmbito da justiça estadual aprimoraria o tempo do processo, ensejando a prestação jurisdicional dentro de um tempo exequível. O objetivo de trabalhar tal problema foi estabelecido a partir da análise do relatório do governo brasileiro chamado Justiça em Números, o qual trouxe dados estatísticos do tempo despendido entre o ajuizamento e a sentença, um tempo processual que torna a justiça morosa e deficitária. A justificativa para pesquisar tal problema é a crescente projeção da informatização dos processos judiciais que visam reduzir a distância entre as partes e o processo, aproximando-o, não se dispensando, contudo, as prerrogativas e os princípios constitucionais. O método empregado é o indutivo, pois parte da análise dos dados da Justiça em Números, perfectibilizando-se na pesquisa bibliográfica, de forma predominante, e documental, com referências à legislação federal.
\end{abstract}

PALAVRAS-CHAVE: Razoável duração do processo. Processo eletrônico. Justiça Estadual do Rio Grande do Sul. Justiça Estadual. Justiça em Números.
ABSTRACT: Access to justice and the pursuit of reasonable duration are procedural principles that strive for effective adjudication. The insertion of section LXXVIII in the cast of individual rights and guarantees (Article 5 of the Brazilian Constitution) aimed, from the beginning, to ensure the reasonable length of proceedings, both in the judicial and administrative spheres. Since then, the Judiciary inserted some systems, including the computerization of the judicial process, adopting faster, more economical and more efficient bureaucratic proceedings. Thus, the research will focus on the analysis of the electronic procedure in the state court of Rio Grande do Sul as a possibility to ensure the reasonable length of the proceedings. In this sense, the problem focuses on checking if the implementation of the electronic proceedings in the state court would improve the proceedings time, allowing for the adjudication within a feasible time. The aim of working on such problem was established from the analysis of the Brazilian government's report called Justiça em Números, which brought statistics of the time spent between the filing of the action and the judgment, a procedural time which makes justice slow and deficient. The justification for researching such problem is the growing projection of computerization of legal proceedings, which aim at reducing the distance between the parts and the procedure, bringing it closer to them, without throwing away, however, the prerogatives and constitutional principles. The method employed is the inductive one, since it begins with the analysis of the data of Justiça em Numeros, improving it with bibliographic research the predominant form, and documentary research, with references to the federal legislation.

KEYWORDS: Reasonable length of proceedings. Electronic proceedings. State Justice of Rio Grande do Sul. State Justice. Justiça em Números (Justice in Numbers).

SUMÁRIO: Introdução. 1. Razoável Duração do Processo. 1.1. Informatização no Poder Judiciário. 2. Processo Eletrônico na Justiça Estadual. Considerações Finais. Referências.

\footnotetext{
* Mestranda do Programa de Pós-graduação Stricto Sensu em Direito pela Universidade de Santa Cruz do Sul (UNISC). Membro do Grupo de Pesquisa CNPq "Políticas Públicas no Tratamento dos Conflitos".

* Docente dos cursos de Graduação e Pós Graduação da UNISC e UNIJUI. Pós-doutora em Direito pela Università degli Studi di Roma Tre, Itália, e Doutora em Direito pela Universidade do Vale do Rio dos Sinos (UNISINOS).
} 


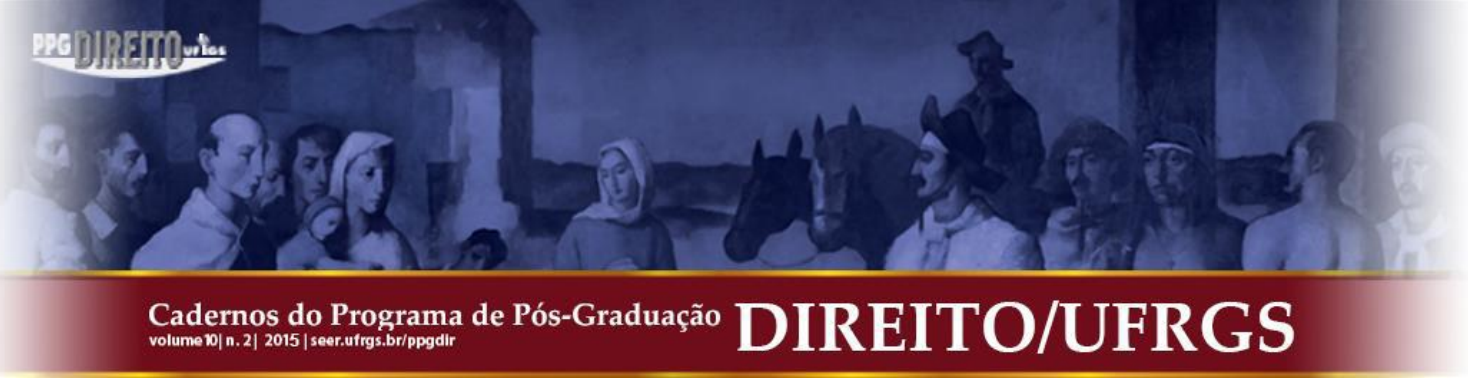

Necessário é o razoável enquanto substancial, e nós somos livres na
medida em que o reconhecemos como lei e seguimos como substância de
nossa própria essência. (George WF Hegel, 1970.p.57)

\section{INTRODUÇÃO}

O presente artigo tem como tema examinar o processo eletrônico no âmbito da Justiça Estadual do Rio Grande do Sul, como uma alternativa capaz de ensejar maior celeridade dentro de prazo razoável.

Neste sentido, o problema incide em verificar se a efetivação do processo eletrônico no âmbito da justiça estadual diminuiria a duração do processo, ensejando a prestação jurisdicional dentro de um tempo exequível. O objetivo de trabalhar tal problema foi estabelecido a partir da análise do relatório Justiça em Números, o qual trouxe dados estatísticos do tempo despendido entre o ajuizamento e a sentença, um período processual que torna a justiça morosa e deficitária. A justificativa para pesquisar tal problema é a crescente projeção da informatização dos processos judiciais que visam reduzir a distância das partes, aproximando-o, em um período curto, não se dispensando, contudo, as prerrogativas e os princípios constitucionais. O método a ser empregado é a indutivo, pois parte da análise dos dados da Justiça em Números, a técnica metodológica é a documentação indireta, perfectibilizando-se na pesquisa bibliográfica, de forma predominante, e documental, com referências a legislação federal.

Assim, estruturou-se o presente artigo em duas partes, sendo que na primeira a proposta é o exame do princípio de razoável duração do processo, ao passo que a segunda contemplará o processo eletrônico no âmbito da Justiça Estadual.

O Poder Judiciário, apoiado na Lei $\mathrm{n}^{\mathrm{o}}$ 11.419/2006, vem dispensando medidas, sob o escopo de disseminar maior celeridade as intimações processuais, mandados e demais diligências que, por longo período, engessaram o trabalho dos serventuários, na medida em que, permaneciam por demasiado período no interior dos Cartórios, aguardando-se uma juntada ou mesmo a edição no Diário Oficial. Passados nove anos desde a publicação da aludida lei, visualiza-se um quadro positivo, visto que, no momento, muitas assinaturas são digitais (com certificação digital), assim, como cartas precatórias e intimações eletrônicas, de caráter urgente.

Contudo, a morosidade processual ainda aufere um espaço grandioso nas Comarcas de $1^{\circ}$ Grau que compõem o Poder Judiciário do Estado do Rio Grande do Sul, com espaços físicos reduzidos, excesso de arquivos inativos, quadro de serventuários diminuídos, fatores que 


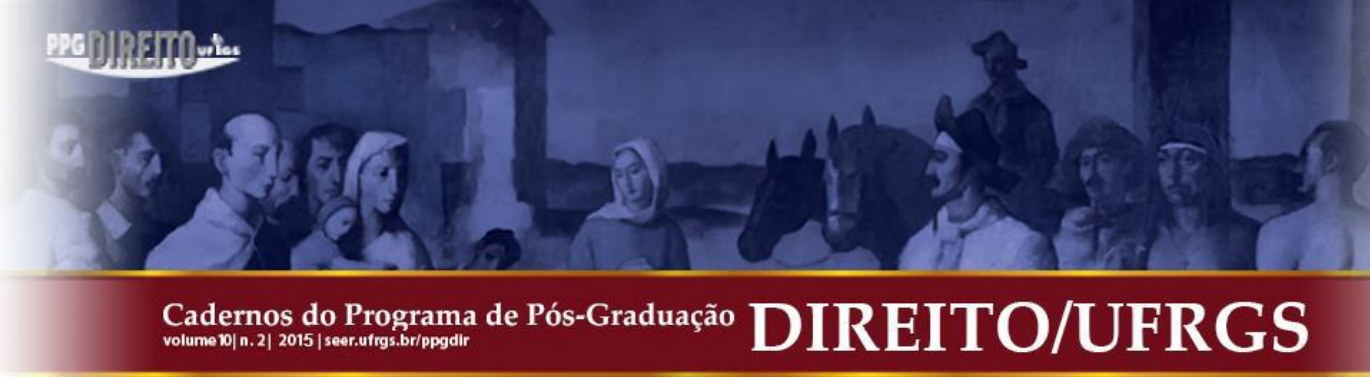

acabaram por reduzir à celeridade processual, dando espaço à morosidade. Assim, como forma de reduzir tal cenário, adveio, a implantação do processo eletrônico em 2012, implantação gradual, que será incorporada de forma gradativa nas Varas Judiciais. O PJe, como será denominado, terá como propósito, primordial, impor maior celeridade, economicidade, praticidade, sem olvidar dos princípios constitucionais.

\title{
1 RAZOÁVEL DURAÇÃO DO PROCESSO
}

A complexidade que gira em torno do tempo processual emerge como um tema de significativa importância, necessitando, por esse motivo, de um olhar mais atento e reflexivo acerca de suas características. Contudo, antes de adentrar, com maior propriedade no tempo processual, faz-se necessário visitar, brevemente, o entendimento de François Ost, acerca do tempo e do direito. O tempo pode ser medido e analisado por meio de vários olhares e Ost faz uma sincronia perfilhando uma reflexão: "Não sei o que é o tempo. Não sei qual a sua verdadeira medida, se é que a possui. A dos relógios, sei que é falsa. Divide o tempo espacialmente, de fora. A das emoções, sei que é falsa, não divide o tempo, mas a sensação do tempo". ${ }^{1}$ E o autor vai além:

\begin{abstract}
O tempo de que fala, enquanto trata de todas as suas outras dimensões, é o presente, pois é no presente que se toca o compasso em quatro tempos do direito. Mas esse presente é uma aposta que nada tem de seguro: ganha-lo é uma questão de responsabilidade- uma questão ética e política, mais do que uma necessidade ontológica. [...] o direito é medida, pelo menos em quatro sentidos que vão da norma ao tempo. Em direito, tomam-se -medidas-: decisões, regras de conduta; fala-se de medidas de ordem pública, de medidas de segurança, de medias conservatórias. [...] está justa medida dos tempos misturados, é preciso sublinhar agora que se joga no presente. [...] Assim se mede uma duração que permite fazer justiça; é dado tempo que permite ao direito exprimir-se. ${ }^{2}$
\end{abstract}

A promessa de duração razoável do processo e a batalha contra o tempo retroagem ao século passado, pois:

\footnotetext{
${ }^{1}$ OST, François. O tempo do direito. Tradução de Maria Fernanda Oliveira. Lisboa: Instituto Piaget, 1999, p. 23 24.

${ }^{2}$ Ibid, p. 425, 426, 429, 435.

Cadernos do Programa de Pós-Graduação em Direito PPGDir./UFRGS | Edição Digital | Porto Alegre | Volume X | Número 2 | 2015 | P. 364 -390
} 


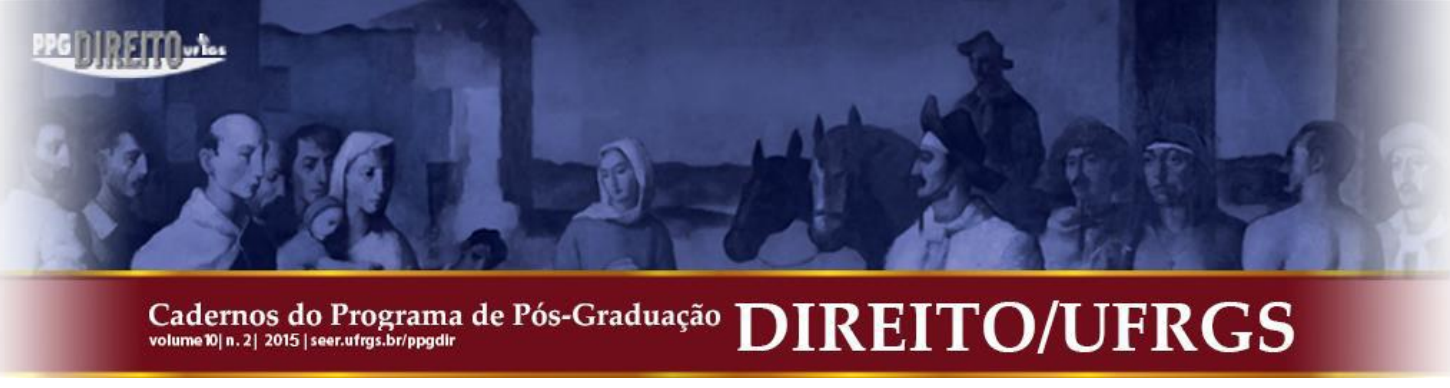

Tempo e Direito relacionam-se com a sociedade, pois não existe tempo fora da história, uma vez que esses três elementos não podem ser isolados tratando-se de uma instituição imaginária, na qual o tempo constrói e é construído, institui e é instituído. ${ }^{3}$

Assim, para Gomes Canotilho, a razoável duração do processo poder-se-ia ser denominada como Princípio da Proibição de Excesso, o qual impõe uma análise relativa ao âmbito específico das leis restritivas de direitos, das liberdades e das garantias, as quais devem ser: adequada (apropriada), necessária (exigível) e proporcional (com justa medida). ${ }^{4}$

O tempo processual está intimamente conectado a imperatividade de impor razoável duração do processo, sobretudo por se tratar de uma garantia constitucional. Para viabilizar a dispensação de tal garantia, tem-se, igualmente, a preocupação com a efetividade processual, sob o escopo de perquirir um ideal de "segurança jurídica com razoável celeridade", conforme pondera Cândido Rangel Dinamarco. ${ }^{5}$

A necessidade de ensejar maior efetividade e celeridade processual transporta-se à imperatividade de um tratamento digno e íntegro, em detrimento ao cenário atual, no qual há litígios demasiadamente morosos nos Cartórios das Comarcas da esfera estadual que compõem o Poder Judiciário, ${ }^{6}$ devido às "desfuncionalidades burocráticas e de gestão ordinária". ${ }^{7}$ No mesmo sentido, Cappelletti e Garth prelecionaram,

Em muitos países, as partes que buscam uma solução judicial precisam esperar dois ou três anos, ou mais, por uma decisão exequível. Os efeitos dessa delonga, especialmente se considerados os índices da inflação, podem ser devastadores. Ela aumenta os custos para as partes e pressiona os economicamente fracos a abandonar suas causas, ou a aceitar acordos por valores muito inferiores àqueles que teriam direito. A Convenção Européia (sic) para a Proteção dos Direitos Humanos e Liberdades Fundamentais reconhece explicitamente, no artigo $6^{\circ}$, parágrafo $1^{\circ}$ que a

\footnotetext{
${ }^{3}$ SPENGLER, Fabiana Marion. Tempo, direito, processo e narrativa: outra abordagem do conflito social. In: COSTA, Marli Marlene Moraes da; LEAL, Mônia Clarissa Hennig. (Org.) Direitos sociais e políticas públicas. Desafios contemporâneos. Tomo 14. Santa Cruz do Sul: EDUNISC, 2014, p.86.

${ }^{4}$ GOMES CANOTILHO, J; J. Direito cconstitucional e tteoria da Constituição. Coimbra: Almedina, 2003.

${ }^{5}$ Processo efetivo não é apenas o que rigorosamente atue a vontade concreta do direito, mas o que seja capaz de cumprir bem os escopos do sistema, vistos em conjunto e compensadas certas deficiências por outras vantagens. O processo que chegue ao ideal de segurança jurídica com razoável celeridade, eliminando o conflito, é eficaz e legitimado pela utilidade social, ainda que falho do ponto-de-vista jurídico. DINAMARCO, Cândido Rangel. $A$ instrumentalidade do processo. 14.ed. São Paulo: Malheiros Editores Ltda., 2009, p. 338.

${ }^{6}$ Considerando o espaço delimitado, cita-se a Ação Cível Originária (ACO) 79, autuada em 06 de junho de 1959, junto ao Supremo Tribunal Federal (STF), e julgada em definitivo, no ano de 2013, após o decurso de cinquenta e quatro anos, com trânsito em julgado em 19.06.2013. Supremo Tribunal Federal, Embargos Declaratórios na Ação Cível Originária 79. Mato Grosso, relator Ministro Teori Zavascki, DJe-103, divulgado 31-05-2013, publicado 0306-2013.Disponível em:< http://redir.stf.jus.br/paginadorpub/paginador.jsp?docTP=TP\&docID=3891427>.Acesso em: 10 jul.2015.

${ }^{7}$ LEAL, Rogério Gesta. Patologias corruptivas nas relações entre estado, administração pública e sociedade: causas, consequências, e tratamento. Santa Cruz do Sul: EDUNISC, 2013, p. 278

Cadernos do Programa de Pós-Graduação em Direito PPGDir./UFRGS | Edição Digital | Porto Alegre | Volume X | Número 2 | 2015 | P. 364 - 390
} 


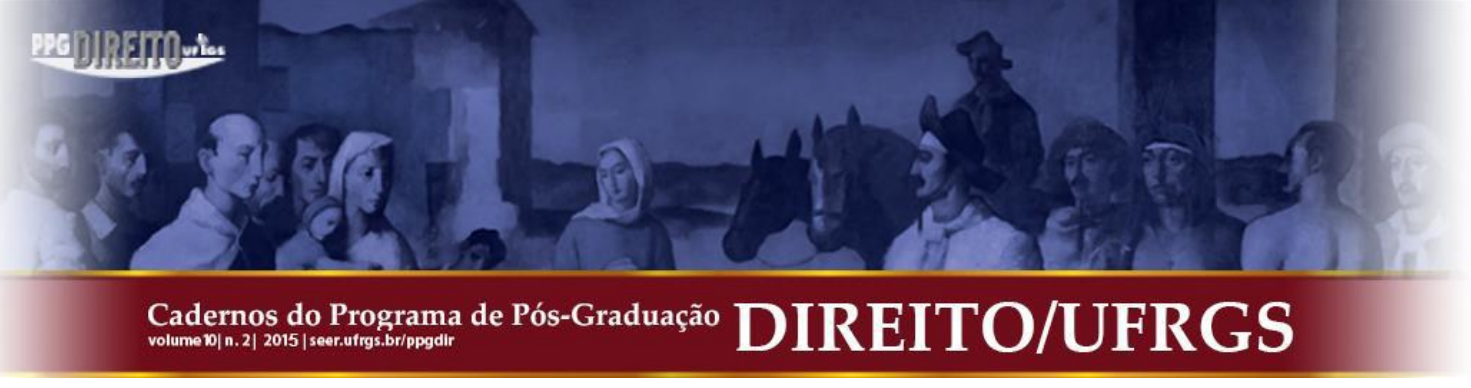

Justiça que não cumpre suas funções dentro de "um prazo razoável” é, para muitas pessoas, uma Justiça inacessível. ${ }^{8}$

Em 1950, norteados pela Declaração Universal dos Direitos Humanos, os Membros do Conselho Europeu, visando assegurar garantia coletiva, aprovaram a Convenção para a Proteção dos Direitos do Homem e das Liberdades Fundamentais prevendo o direito a um processo equitativo, a ser julgado num prazo razoável, determinando que:

\begin{abstract}
Qualquer pessoa tem direito a que a sua causa seja examinada, equitativa e publicamente, num prazo razoável por um tribunal independente e imparcial, estabelecido pela lei, o qual decidirá, quer sobre a determinação dos seus direitos e obrigações de carácter civil, quer sobre o fundamento de qualquer acusação em matéria penal dirigida contra ela. $\mathrm{O}$ julgamento deve ser público, mas o acesso à sala de audiências pode ser proibido à imprensa ou ao público durante a totalidade ou parte do processo, quando a bem da moralidade, da ordem pública ou da segurança nacional numa sociedade democrática, quando os interesses de menores ou a protecção (sic) da vida privada das partes no processo o exigirem, ou, na medida julgada estritamente necessária pelo tribunal, quando, em circunstâncias especiais, a publicidade pudesse ser prejudicial para os interesses da justiça. ${ }^{9}$
\end{abstract}

A razoável duração do processo encontrou-se demarcada em outro precedente normativo importante. A Convenção Americana de Direitos Humanos, igualmente conhecida como Pacto de San José da Costa Rica, aberta à assinatura em 22 de novembro de 1969, sendo aprovada pelo Congresso Nacional em 1992 e, internalizada por meio do Decreto 678, de 09 de novembro de $1992,{ }^{10}$ previu no artigo $8^{\circ}$ que "toda pessoa tem direito de ser ouvida com as devidas garantias e dentro de um prazo razoável, por um juiz ou tribunal competente, independente e imparcial [...]”. O País alicerçado em tais Convenções enfrentava, ainda, uma burocracia que implicava em procedimentos morosos.

Para divulgar o quadro penoso vivenciado pelo Poder Judiciário, o Conselho Nacional de Justiça, por meio do projeto Justiça em Números apresentou os indicadores anuais: para o ano de 2003, a Justiça Estadual de $1^{\circ}$ Grau do Estado do Rio Grande do Sul contava com

\footnotetext{
${ }^{8}$ CAPPELLETTI, Mauro; GARTH, Bryant. O acesso à justiça. Tradução de Ellen Gracie Northfleet. Porto Alegre: Sergio Antonio Fabris, 1988, p.20.

9 CONVENÇÃO Europeia dos Direitos do Homem. Disponível em: <http://www.echr.coe.int/Documents/Convention_POR.pdf>. Acesso em 10 jul.2015.

${ }^{10}$ BRASIL (1992). Decreto $n^{\circ} 678$, de 06 de novembro de 1992. Promulga a Convenção Americana sobre Direitos Humanos (Pacto de São José da Costa Rica), de 22 de novembro de 1969. Disponível em: < http://www.planalto.gov.br/ccivil_03/decreto/D0678.htm>. Acesso em: 08 jul.2015. 


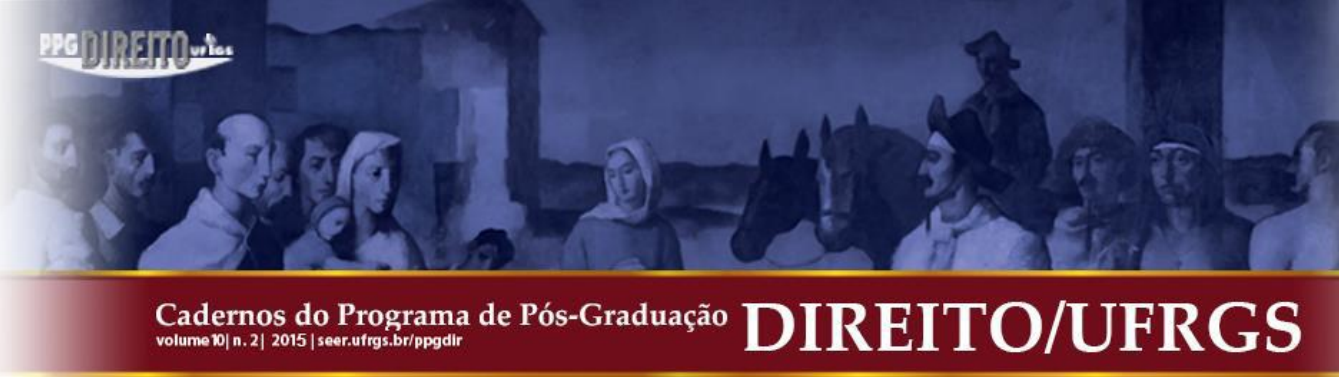

9.107,81 casos novos (por 100.000 habitantes). O número de casos novos por Magistrados no $2^{\circ}$ Grau totalizou $1.424,84 .^{11}$

Diante deste cenário, adveio a Emenda Constitucional $n^{\circ} 45 / 2004$, ordinariamente, denominada Reforma do Judiciário. Dentre as inúmeras alterações constitucionais, houve a apreensão com a morosidade processual que preocupava a sociedade e o próprio Judiciário há décadas.

Assim, o legislador constitucional, visando uma garantia razoável a duração do processo, incluiu no rol de Garantias Fundamentais do artigo $5^{\circ}$, o inciso LXXVIII, da Constituição Federal do Brasil, o qual previu que "a todos, no âmbito judicial e administrativo, são assegurados a razoável duração do processo e os meios que garantam a celeridade de sua tramitação". ${ }^{12}$ Com a inserção, acreditava-se que haveria um estabelecimento de uma ordem jurídica plena e efetiva, atendendo a necessária conclamação de uma celeridade processual, justa e eficaz, em detrimento à morosidade que há tempo preponderava.

A Constituição Federal não previu de forma literal a terminologia "acesso à justiça", porquanto o inciso XXXV prediz que "a lei não excluirá da apreciação do Poder Judiciário lesão ou ameaça a direito" A construção dialética acerca da proteção jurisdicional do indivíduo frente ao Poder Judiciário, estabelecendo a apreciação das lesões ou ameaça ao direito, compreende o dimensionamento de garantias fundantes que possibilitam a instrumentalização para o exercício da cidadania plena.

$\mathrm{O}$ acesso à justiça, não obstante não se esgotar no acesso ao Judiciário, conforme pondera Spengler, ${ }^{13}$ traduz-se em um requisito fundamental de um sistema jurídico moderno e igualitário que pretenda garantir os direitos de todos, conforme lecionam Mauro Cappelletti e Bryant Garth, ${ }^{14}$ conduzindo, portanto, uma tutela que visa à proteção efetiva, a ser suportada pelo Estado, de forma eficiente e tempestiva. ${ }^{15}$

\footnotetext{
${ }^{11}$ BRASIL. Conselho Nacional de Justiça. Disponível em: 〈http://www.cnj.jus.br/gestao-e-planejamento/metas.> Acesso em: 06 jul. 2015.

${ }^{12}$ BRASIL (2004). Emenda Constitucional $n^{\circ} 45$, de 30 de dezembro de 2004. Altera dispositivos dos arts. $5^{\circ}, 36$, 52, 92, 93, 95, 98, 99, 102, 103, 104, 105, 107, 109, 111, 112, 114, 115, 125, 126, 127, 128, 129, 134 e 168 da Constituição Federal, e acrescenta os arts. 103-A, 103B, 111-A e 130-A, e dá outras providências. Disponível em: < http://www.planalto.gov.br/ccivil_03/constituicao/Emendas/Emc/emc45.htm>. Acesso em: 06 jul. 2015.

${ }^{13}$ SPENGLER, Fabiana Marion. Tempo, direito e Constituição: reflexos na prestação jurisdicional do Estado. Porto Alegre: Do Advogado, 2008, p. 50.

${ }^{14}$ CAPPELLETTI, Mauro; GARTH, Bryant. op. cit., p. 12.

15 ALEXY, Robert. Teoria dos direitos fundamentais. Tradução de Virgílio Afonso da Silva. 2. ed. São Paulo: Malheiros Editores, 2011. 


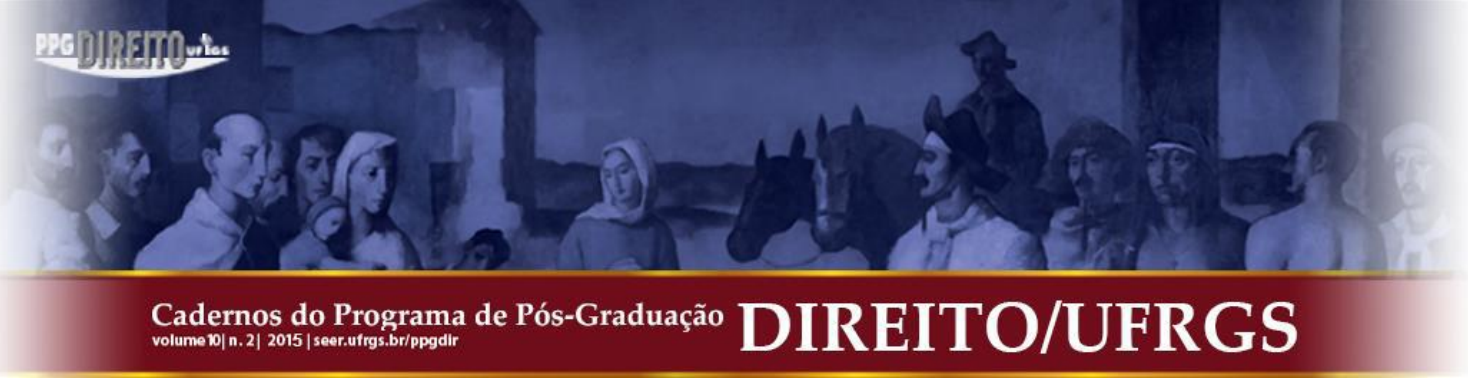

No mesmo sentido ventilado por Cappelletti e Garth, ao demonstrar a possibilidade de fomentar acesso à justiça por meios alternativos, visando à efetiva prestação jurisdicional, Boaventura de Sousa Santos também aventou impulsionar a análise quando da edição da obra intitulada Para uma Revolução Democrática da Justiça, na qual propôs formas de solucionar conflitos, por meio de uma democratização do acesso ao direito, trabalhando-se a necessidade de examinar duas vertentes: a morosidade sistêmica e a morosidade ativa. ${ }^{16}$ Neste sentido, frisou que "a morosidade sistémica ${ }^{17}$ é aquela que decorre da sobrecarga de trabalho, do excesso de burocracia, positivismo e legalismo", ${ }^{18}$ ao passo que a morosidade ativa se trata de quaisquer empecilhos impulsionados pelos atores processuais que acabam prejudicando "a sequência normal dos procedimentos com vista ao desfecho do caso". ${ }^{19}$ Para ambos, Santos sinaliza que a busca pela celeridade, sob o argumento de uma justiça mais rápida/célere, não pode justificar o afastamento da prestação de uma justiça cidadã.

A análise temática enseja um repensar, subjugando-se a assertiva de inversão do modo da construção dogmática, ordinariamente propugnada na forma horizontal. A inversão dogmática transpõe um exame de forma vertical, impondo de maneira linear uma constituição dos pressupostos normativos, possibilitando, assim, uma conjugação de dogmas, além de valores sociais e políticos, que estabelecem uma justiça social eficiente, capaz de resolver os conflitos sociais e dirimir os litígios, dentro de um prazo razoável condizente com as necessidades dos indivíduos.

Além de promover a ampla efetividade do acesso à justiça, a eficiência também deve ser observada, a qual não se resume ao menor custo, devendo ser considerados outros elementos. Para tanto, Humberto Ávila leciona:

A eficiência compreende o dever de adotar o meio menos custoso ceteris paribus, o
que, para alguns, consiste no dever de a administração escolher dentre as várias
alternativas aquela que implique menos dispêndios financeiros. O custo administrativo
pode ser considerado de modo absoluto, no sentido de que a opção menos onerosa
deve ser acolhida sempre, independentemente de outras alternativas, apesar de mais
custosas, apresentarem outras vantagens; ou de modo relativo, no sentido de que a
opção menos onerosa deve ser adotada somente se as vantagens proporcionadas por
outros meios não superarem o benefício financeiro. Este último parece ser o que
melhor se amolda ao ordenamento jurídico brasileiro, porque nem sempre o
equipamento mais barato é o mais adequado para realizar a finalidade de modo

16 SANTOS, Boaventura de Sousa. Para uma revolução democrática da justiça. 3. ed. São Paulo: Cortez, 2011SANTOS, 2014, p. 41-45

${ }^{17}$ Grafia no original

${ }^{18}$ SANTOS. op. cit., p. 44

${ }^{19}$ Ibid, p. 49

Cadernos do Programa de Pós-Graduação em Direito PPGDir./UFRGS | Edição Digital | Porto Alegre | Volume X | Número 2 | 2015 | P. 364 - 390 


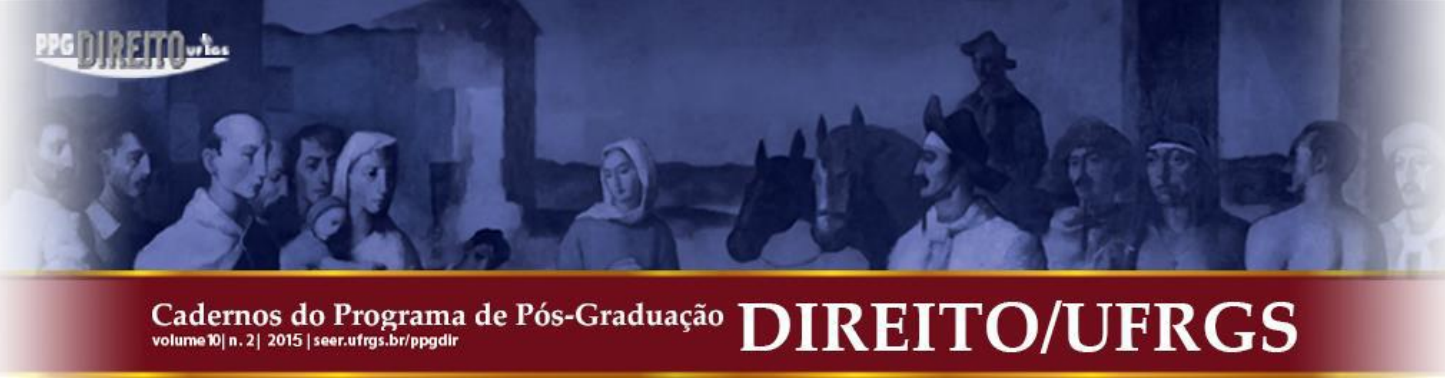

A temporalização e a destemporalização do Tempo e do Direito, transvestidos em duas faces, dois movimentos, não obstante não consignarem vocábulos sinônimos, tende a caminharem próximos, primando por uma justiça social, que não seja um fim em si, mas que permita assegurar um tempo, considerado por François Ost e Boaventura de Sousa Santos como tempo justo.

A preocupação com o tempo esculpida no termo "morosidade", também, permeou ações do Conselho Nacional de Justiça, o qual, anualmente, promove, de forma quantitativa, a análise dos dados, da produtividade dos processos, dos recursos humanos e dos recursos materiais dispendidos pelo Poder Judiciário, em todo território nacional. Assim, a partir dos indicadores divulgados pelo Conselho Nacional de Justiça $(\mathrm{CNJ})^{24}$ tornou-se possível dimensionar os percalços vivenciados pela sociedade em face da morosidade processual demarcada por um "tempo morto". 25

Não obstante a importância da Justiça em Números, para possibilitar o acompanhamento dos indicadores, Alexandre Morais da Rosa e Julio Cesar Marcellino Júnior, ${ }^{26}$ sublinham que, por cautela, o serviço público não pode ser pormenorizado em "atividade matematizada", importando-se apenas com a produtividade numérica e estatística em detrimento a finalidade essencial do serviço público, a qual prima pela prestação jurisdicional efetiva. Em igual posicionamento, Raquel Tomé Soveral e Luciano de Araújo Migliavacca, atentam que, muito embora, mostra-se importante o aprimoramento e a redução da burocracia processual, não se pode "deixar que a celeridade prevaleça sobre a segurança jurídica das decisões". 27

O Conselho Nacional de Justiça, a fim de fomentar dispositivos capazes de alicerçar o cumprimento do princípio constitucional de razoável duração do processo, projetou Metas, ${ }^{28}$ iniciando-se com a Meta 2, que visava descongestionar o estoque de processos,

\footnotetext{
${ }^{24}$ BRASIL. Conselho Nacional de Justiça. Disponível em: <http://www.cnj.jus.br/gestao-e-planejamento/metas.> Acesso em: 06 jul. 2015.

${ }^{25}$ Trata-se do tempo em que o processo permanece dentro das Cartórios das Comarcas da esfera estadual, aguardando, em cima das mesas ou estantes, alguma diligência, juntada, despacho ou mesmo a prolação da sentença.

${ }^{26}$ ROSA, Alexandre Morais da; MARCELLINO JR, Julio Cesar. O (re)pensar da crise jurisdicional diante do engodo eficientista: o direito e a economia em discussão. In: SPENGLER, Fabiana Marion; BRANDÃO, Paulo de Tardo. Os (des) caminhos da jurisdição. Florianópolis: Conceito Editorial, 2009, p. 55.

${ }^{27}$ SOVERAL, Raquel Tomé. MIGLIAVACCA, Luciano de Araújo. Reforma do Código de processo civil: a busca pela razoável duração do processo, como direito fundamental, frente às garantias processuais. Disponível em: <https://seer.imed.edu.br/index.php/revistadedireito/index>. Acesso em: 24 out.2015.

${ }^{28}$ As metas nacionais do Poder Judiciário, inicialmente metas de nivelamento, foram definidas pela primeira vez no $2^{\circ}$ Encontro Nacional do Judiciário, que aconteceu em Belo Horizonte, Minas Gerais, em 2009. Ao final do Encontro, os tribunais brasileiros traçaram 10 metas de nivelamento para o Judiciário no ano de 2009 . O grande destaque foi a Meta 2, que determinou aos tribunais que identificassem e julgassem os processos judiciais mais 


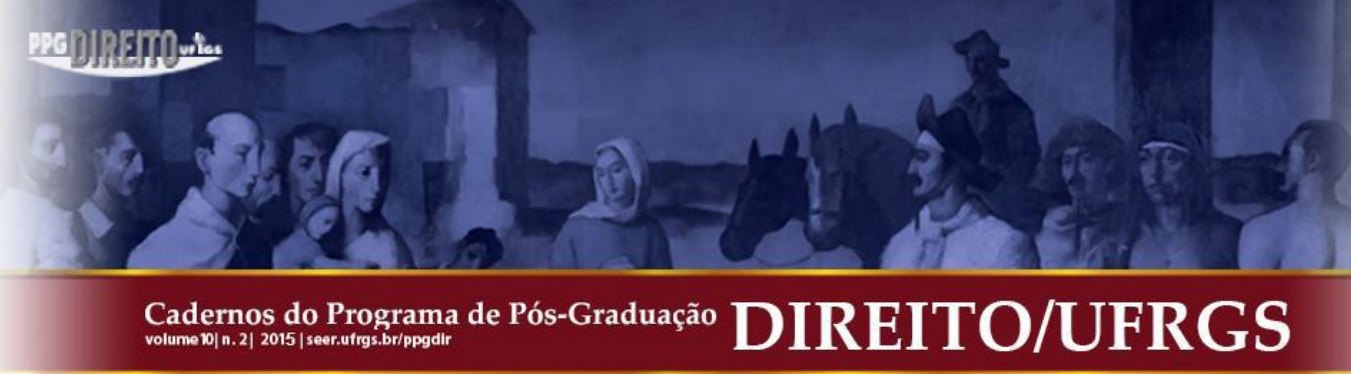

[...] o Poder Judiciário começou a se alinhar com o direito constitucional de todos os cidadãos brasileiros que estabelece a duração razoável do processo na Justiça. Foi o começo de uma luta que contagiou o Poder Judiciário do país para acabar com o estoque de processos causadores de altas taxas de congestionamento nos tribunais. Também foram definidas outras metas importantes para organizar o trabalho nas varas de Justiça, informatizar o Judiciário e proporcionar mais transparência à sociedade. ${ }^{29}$

O relatório de $2014^{30}$ originou um panorama mais expressivo, contendo cerca de setenta e oito por cento (78\%) dos processos em tramitação na Justiça Estadual,

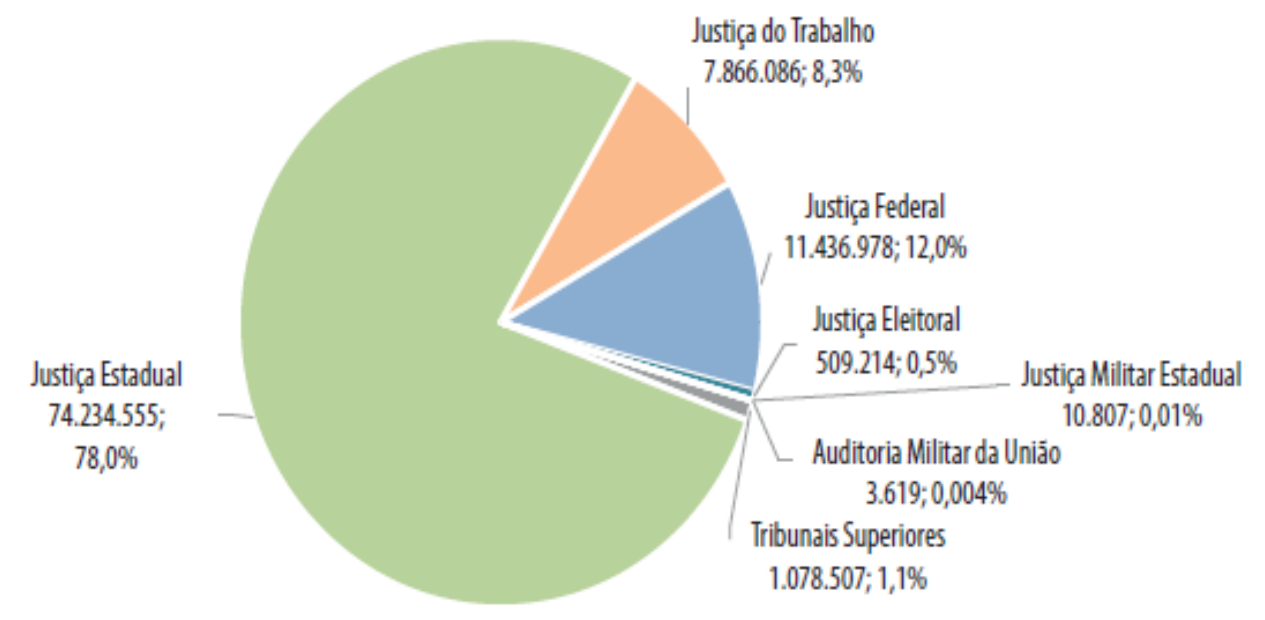

Gráfico 10 - Total de processos em tramitação por ramo de justiça

(Fonte: Conselho Nacional de Justiça) ${ }^{31}$

O Estado do Rio Grande do Sul encontra-se alocado no ranking do $1^{\mathrm{o}}$ porte, tendo, portanto, cerca de 4.436 .773 processos em tramitação. Tais números refletem, porém não dimensionam com precisão os prejuízos decorrentes do tempo do processo. Dependendo do objeto e das partes que litigam, o tempo pode ser compreendido de forma diferente. Como exemplo, cita-se a situação de uma criança que se encontra necessitando de uma pensão alimentícia. Para ela, 24h representa um tempo enorme, pois necessita que o alimentante

antigos, distribuídos aos magistrados até 31.12.2005. Com a Meta 2, o Poder Judiciário começou a se alinhar com o direito constitucional de todos os cidadãos brasileiros que estabelece a duração razoável do processo na Justiça. BRASIL. Conselho Nacional de Justiça. Disponível em: <http://www.cnj.jus.br/gestao-e-planejamento/metas.> Acesso em: 06 jul. 2015.

${ }^{29}$ Ibid.

${ }^{30}$ Despesa total em 2013, com TJRS: R $\$ 2.070 .026,368$ (bens e serviços R $\$ 269.205,24$ ) RH R \$ 1.800.820,644, ativos: $\mathrm{R} \$ 1.084 .297,588$ e inativos $\mathrm{R} \$ 560.977,216, \mathrm{R} \$ 71.124,30$ em informática). Contava com 588 magistrados e 5.594 servidores da aera judiciaria e, para o $2^{\circ}$ Grau o número de Magistrados contabilizados alcançaram 136 e 1.127 servidores para área judiciaria. O número de magistrados para a TR e JE totalizaram 235, enquanto e área administrativa contabilizou 1.177). Dados extraídos do relatório Justiça em Números 2014. BRASIL. Conselho Nacional de Justiça. Disponível em: <http://www.cnj.jus.br/gestao-e-planejamento/metas.> Acesso em: 06 jul. 2015.

31 Ibid.

Cadernos do Programa de Pós-Graduação em Direito PPGDir./UFRgS | Edição Digital | Porto Alegre | Volume X | Número 2 | 2015 | P. 364 - 390 


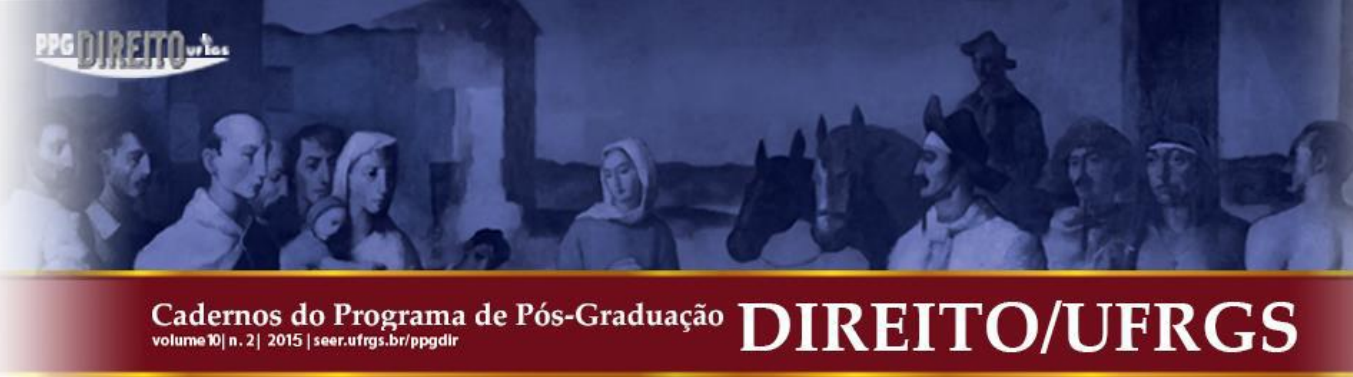

alcance (através da intervenção estatal) o valor para poder se alimentar. O preso que aguarda a liberdade provisória tem nos milésimos de segundo a dimensão de meses. E, em contrapartida, quem aguarda a distribuição de uma ação reivindicatória de posse, o tempo da demanda atingirá ambos, seja o invasor ou o proprietário.

Necessário repisar que, a Reforma do Judiciário previu, ainda, alicerçar novas resoluções de conflitos, tais como a implementação da conciliação, arbitragem e mediação, sistemáticas que tentam, na medida do possível, aventar o conflito e não apenas a resolução do litígio.

Com a entrada do Novo Código de Processo Civil (CPC) em 2016, por meio da Lei $\mathrm{n}^{\circ}$ 13.105, haverá a previsão expressa quanto à observância do tempo razoável para o processo: Art. 4- As partes têm o direito de obter em prazo razoável a solução integral do mérito,
incluída a atividade satisfativa.
Art. 6- Todos os sujeitos do processo devem cooperar entre si para que se obtenha, em
tempo razoável, decisão de mérito justa e efetiva.

A garantia à prestação jurisdicional digna e condizente à pessoa humana, também encontrar-se-á em destaque no artigo $8^{\circ}$ do novo CPC, registrando que "Ao aplicar o ordenamento jurídico, o juiz atenderá aos fins sociais e às exigências do bem comum, resguardando e promovendo a dignidade da pessoa humana e observando a proporcionalidade, a razoabilidade, a legalidade, a publicidade e a eficiência". ${ }^{33}$ A demora provocada, com exclusividade, pelo serviço judiciário, igualmente, não deverá prejudicar as partes litigantes, conforme preceitua o $\$ 3^{\circ}$ do artigo 240 do novo CPC. ${ }^{34}$

Tais medidas sinalizam certa preocupação com a celeridade processual, não se olvidando em primar pela promoção dos princípios constitucionais que asseguraram a ampla defesa e ao contraditório, de forma contínua e permanente.

\subsection{Informatização no Poder Judiciário}

32 BRASIL, (2015). Lei $n^{o}$ 13.105, de 16 de março de 2015. Código de processo civil. Disponível em: <http://www.planalto.gov.br/ccivil_03/_Ato2015-2018/2015/Lei/L13105.htm>. Acesso em: 27 jul.2015.

33 Ibid.

${ }^{34}$ Ibid.

Cadernos do Programa de Pós-Graduação em Direito PPGDir./UFRgS | Edição Digital | Porto Alegre | Volume X | Número 2 | 2015 | P. 364 - 390 


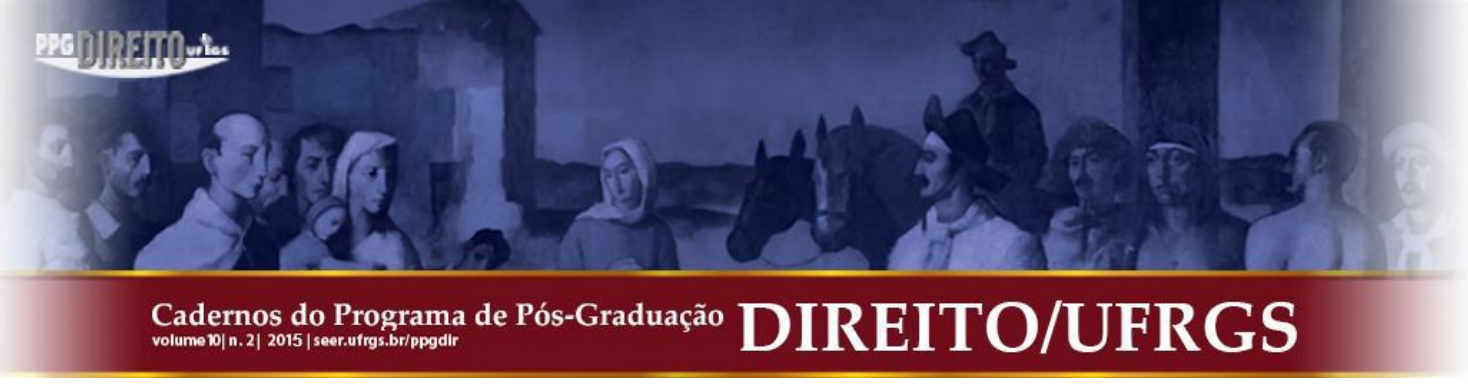

A tecnologia e a informatização demarcam um território que antigamente era incólume, quiçá reservado para alguns profissionais. $\mathrm{Na}$ atualidade, a informática tomou um espaço territorial incomensurável, sendo utilizada de forma desmedida pela sociedade.

O uso desacelerado na utilização e na má-utilização (como nos casos dos crimes virtuais envolvendo a pornografia infantil) impulsionou a consagração da $5^{\mathrm{a}}$ Dimensão dos Direitos Virtuais, assegurando os direitos advindos das tecnologias de informação (Internet), do ciberespaço e da realidade virtual em geral. Para Antonio Carlos Wolkmer, ${ }^{35}$ faz-se necessário dispensar uma maior preocupação em relação aos direitos virtuais, visto que a virtualização de dados demandaria um controle normativo e judicial. ${ }^{36}$

Há algum tempo, a informática vem ganhando espaço nos Cartórios das Comarcas Estaduais, que ampliaram o sistema informatizado, reduzindo, por certo, o "tempo morto" do processo. Antes da implementação do sistema informatizado, a procura por um processo era demasiadamente prolongada, uma vez que necessitavam localizar as anotações lançadas nos livros. Atualmente, utiliza-se o sistema de busca no computador e a localização do processo se dá em um milésimo de segundo, aproximadamente.

Porém, outras medidas ainda necessitam do servidor, tais como a distribuição, a perfuração das folhas, a numeração com o lançamento manual da rubrica, a juntada das petições e mandados. ${ }^{37}$ Acredita-se que, o procedimento moroso, tangenciado ao procedimento de formalismo, exacerbado, que se alojou no interior das Comarcas Estaduais reflete negativamente, visto que tais fatores acabaram por aumentar o tempo do processo, isso porque, o período despendido entre o ajuizamento e a sentença é de cerca de duzentos (200) dias, podendo chegar a anos, dependendo do litígio e da forma de instrução processual, bem como da estrutura física do Cartório, conforme análise promovida pelo Conselho Nacional de Justiça.

Além disso, tem-se que,

A burocracia é um dos entraves para o cidadão ter acesso a uma Justiça rápida. Segundo números divulgados pelo Conselho Nacional de Justiça (CNJ), cerca de $70 \%$

\footnotetext{
35 RUBIO, David Sanchez; FLORES, Joaquim Herrera; CARVALHO, Salo de (Orgs.). Direitos Humanos e globalização: fundamentos e possibilidades desde a teoria crítica. Anuário Iberoamericano de Direitos Humanos (2003/2004). 2. ed. Porto Alegre: EDIPUCRS, 2010, p.1-109. Disponível em: <http://www.pucrs.br/edipucrs/direitoshumanos.pdf>. Acesso em: 12 set.2015.

${ }^{36}$ Ibid.

${ }^{37}$ As assinaturas dos Magistrados Estaduais eram lançadas manualmente; com o advento da lei $\mathrm{n}^{\circ}$ 11.419/2006, implantaram o sistema de "assinatura digital",reduzindo-se significativamente o tempo de espera pela assinatura do Juiz competente.

Cadernos do Programa de Pós-Graduação em Direito PPGDir./UFRGS | Edição Digital | Porto Alegre | Volume X | Número 2 | 2015 | P. 364 - 390
} 


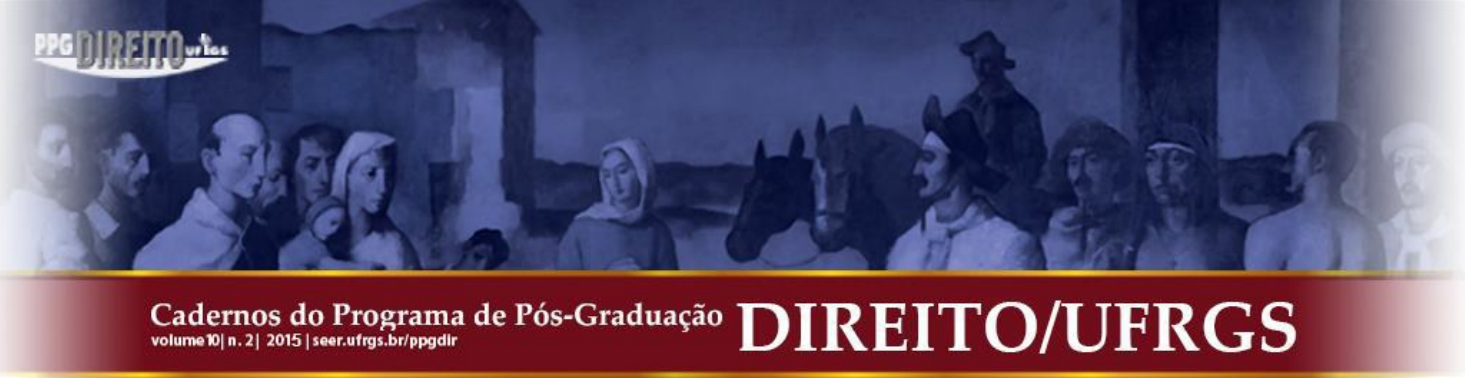

do tempo de tramitação de um processo são perdidos no vai e vem de papéis entre gabinetes, protocolos e cartórios. ${ }^{38}$

O cenário é mais acentuado nas Varas Judiciais (únicas), que contam com apenas um Magistrado, o qual é responsável e competente por todas as demandas (cível, penal, juizado, fazenda pública, entre outras), inclusive a Direção do Foro.

Assim, acredita-se que o sistema de informatização, bem como, a introdução da Meta 2 e a inserção de garantias constitucionais, com fulcro do inciso LXXVIII do artigo $5^{\circ}$ da Constituição Federal representou elevada melhoria. Porém, ainda faz-se necessário despender esforços para objetivar o progresso nos Cartórios que compõem o $1^{\circ}$ Grau do Tribunal de Justiça do Estado do Rio Grande do Sul. A primeira medida é o investimento financeiro, para ampliar o quadro de servidores, promoção de treinamentos e melhorias da estrutura física, redução da carga da jornada de trabalho, como meio de possibilitar a formação continuada; ampliação dos espaços de discussões dos conflitos, como forma de trata-los, por meio da inserção de equipes multidisciplinares.

Além dos investimentos financeiros, que por certo devem ser planejados e executados pelo Executivo, também se fomenta a possibilidade de ensejar uma duração razoável do tempo processual, com a implementação efetiva do processo eletrônico na Justiça Estadual, a exemplo do processo eletrônico implantado, de forma integral, pela Justiça Federal $1^{\circ}$ Grau, do Rio Grande do Sul, em 2010.

\section{PROCESSO ELETRÔNICO NA JUSTIÇA ESTADUAL}

Com o advento da Lei 11.419, em 19 de dezembro de 2006, dispondo sobre a informatização do processo judicial, o Poder Judiciário iniciou o processo de absorção da possibilidade do ideário de tramitação dos processos de forma virtual,

\footnotetext{
Art. $1^{\circ} \mathrm{O}$ uso de meio eletrônico na tramitação de processos judiciais, comunicação de atos e transmissão de peças processuais será admitido nos termos desta Lei.

$\S 1^{\mathrm{o}}$ Aplica-se o disposto nesta Lei, indistintamente, aos processos civil, penal e trabalhista, bem como aos juizados especiais, em qualquer grau de jurisdição. ${ }^{39}$
}

\footnotetext{
${ }^{38}$ AGÊNCIA Brasil. Clipping: Novo sistema pode reduzir em até 70\% tempo de tramitação de processo na Justiça. Disponível em: <http://www.sindiregis.com.br/not.php?id=2275>. Acesso 24 jun. 2015.

${ }^{39}$ BRASIL, (2006). Lei $n^{o} 11.419$, de 19 de dezembro de 2006. Dispõe sobre a informatização do processo judicial; altera a Lei n⿳o 5.869, de 11 de janeiro de 1973 - Código de Processo Civil; e dá outras providências. Disponível em: < http://www.planalto.gov.br/ccivil_03/_ato2004-2006/2006/lei/111419.htm>. Acesso: 24 jun. 2015. 


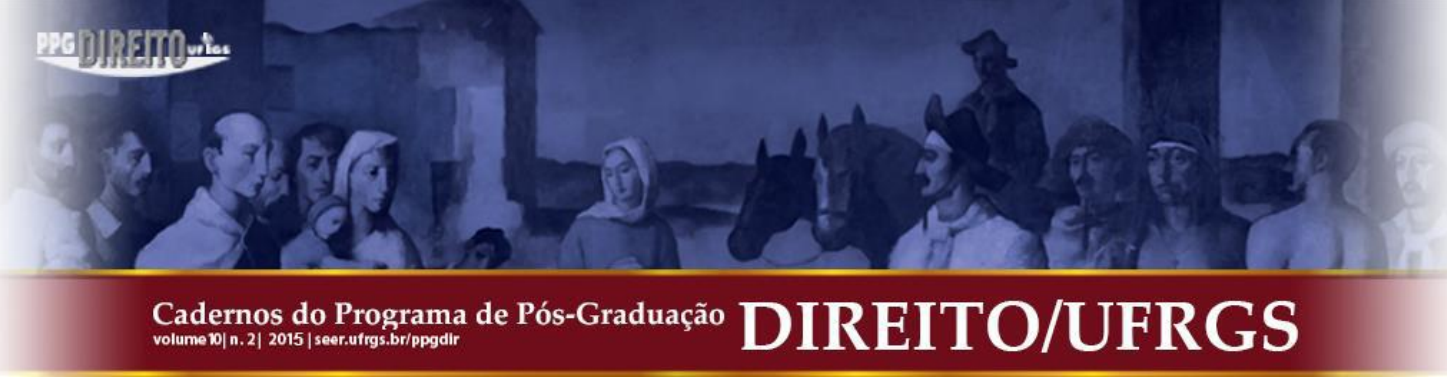

O processo eletrônico é, portanto, o método utilizado como meio, para possibilitar a dinâmica processual, permitindo, assim, a utilização de formas eletrônicas, conforme previsão legal do artigo $1^{\circ}$ da Lei $n^{\circ} 11.419 / 2006$. Tal mecanização pressupõe que, embora seja enviado e mantido exclusivamente por meio do meio eletrônico, deve garantir, em todos os atos, a ampla defesa e o contraditório, ensejando-se observância ao devido processo legal.

Muito embora a informatização dos documentos públicos mostra-se de extrema relevância para a contemporaneidade, em razão da celeridade imposta e da possibilidade do armazenamento de dados processuais junto aos sistemas informatizados, a virtualização total dos processos, ainda, enfrenta algumas críticas, em razão da imperatividade de manutenção do raciocínio humano, em especial, quando da tomada de decisões. Neste sentido, Patrícia Amaral Milbradt repisa que,

\begin{abstract}
A virtualização do sistema processual não constitui uma medida de burocratização informática, mas, sim, uma mudança de paradigma que atinge a forma de praticar atos processuais. A concepção do processo digital (sem a utilização do papel) é extremamente válida, desde que não se traduza na substituição do trabalho do homem pela máquina. O computador é mero instrumento para a concretização do ideal de dar celeridade aos tramites judiciais e, em hipótese alguma, supre a necessidade de o magistrado cercar-se de todos os elementos de prova produzidos nos autos e, servindose de sua inteligência, bom senso e conhecimentos jurídicos, proferir a sentença que entenda ser a mais correta para o caso concreto. Por isso, é que deve ser afastada a possibilidade de serem produzidas decisões cartesianas, ou seja, com o simples preenchimento de dados no computador, pois nenhuma máquina é capaz de substituir o raciocínio humano. ${ }^{40}$
\end{abstract}

Petrônio Calmon, por sua vez, entende pela necessidade de dispensar igual tratamento à Justiça Eleitoral e à Militar, como forma de abranger as demais áreas especializadas, para tanto leciona que:

O que se indaga, entretanto, é o motivo de se ter elaborado uma lei genérica sobre o tema da informatização do processo judicial acompanhado de alterações apenas no Código de Processo Civil. Ou bem se alterariam os três códigos ou essas alterações não seriam necessárias. [...] Se o legislador entendeu que a nova lei não seria eficiente, a ponto de ter promovido alterações diretamente no Código de Processo Civil, é evidente que alterações também seriam necessárias nos demais ordenamentos processuais, não só no Código de Processo Penal e na Consolidação das Leis do

\footnotetext{
${ }^{40}$ MILBRADT, Patrícia Amaral. A efetividade do acesso à justiça por meio do processo eletrônico. Monografia apresentada no curso de graduação da Universidade Federal do Rio Grande do Sul, 2010. Disponível em: <https://www.lume.ufrgs.br/bitstream/handle/10183/27084/000763586.pdf?sequence=1 .> Acesso em: 12 out.2015.

Cadernos do Programa de Pós-Graduação em Direito PPGDir./UFRGS | Edição Digital | Porto Alegre | Volume X | Número 2 | 2015 | P. 364 - 390
} 


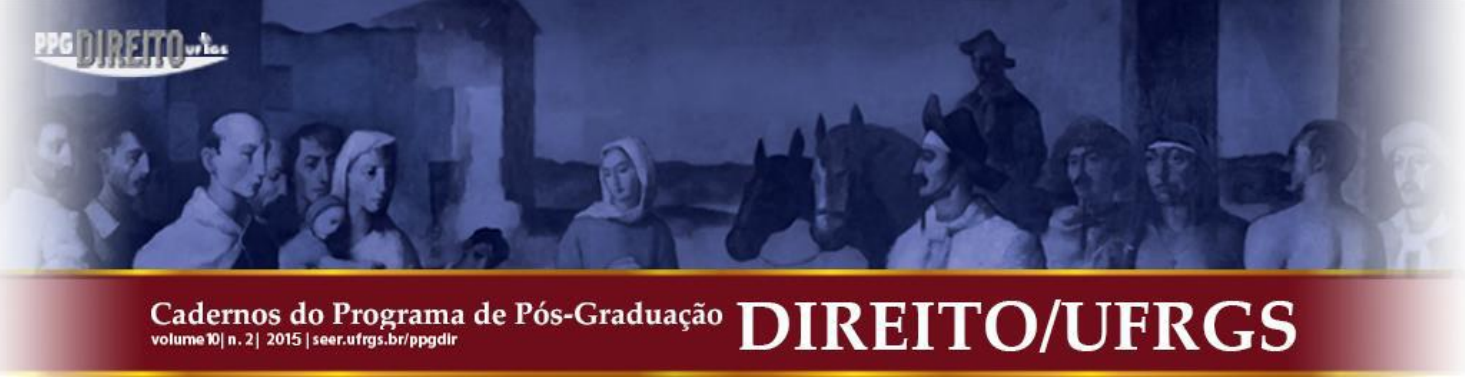

Trabalho, mas, igualmente, nas leis sobre os juizados especiais, nas leis eleitorais e no código de processo militar. ${ }^{41}$

A informática demanda a necessidade de dispor de um computador, equipamento que, por vezes, causa onerosidade ao cidadão ou mesmo ao profissional que, em face da ausência de recursos financeiros não dispõe de meios para aquisição de uma máquina. Além disso, para manusear e navegar no ambiente eletrônico é de extrema necessidade a inclusão digital. ${ }^{42}$

Sobretudo, tem-se que, a inclusão digital, a priori, no âmbito do processo, não se resume a mera digitalização, substituindo-se o papel pela imagem em PDF, tampouco ao acesso a plataforma digital, demandando preparação dos profissionais e dos indivíduos que a utilizarão. Além disso, a era digital também impõe a necessidade de mecanizar "sistemas inteligentes", como sustenta Renato Luis Benucci:

Um sistema inteligente é uma aplicação informática que procura capturar
conhecimento e utilizá-lo para a solução de problemas concretos. Isto se obtém
automatizando o procedimento de tomada de decisões, e consta fundamentalmente de
uma base de conhecimento, um dispositivo lógico e uma interface de diálogo com o
usuário. A base de conhecimento é um repositório de armazenamento de informações.
O dispositivo lógico é o algoritmo ou conjunto de algoritmos que implementam as
regras de raciocínio e conclusões sobre um problema determinado. A interface de
diálogo estabelece o mecanismo pelo qual o usuário e o sistema interagem, de maneira
que o primeiro possa proporcionar a informação requerida para a interpretação do caso
e que o segundo possa logo externar a resposta ou respostas geradas. A utilidade de
sistema inteligentes nas diversas áreas de conhecimento pode proporcionar: economia
de tempo e de recursos e melhoria da qualidade média das decisões.

No Rio Grande do Sul, o processo eletrônico emergiu em meados de 2010. Ainda, no decorrer do mesmo ano, restou publicada a Resolução 17, que previa a implementação, integral, do processo eletrônico na Justiça Federal $(e-p r o c),{ }^{44}$ porquanto, na Justiça do Trabalho (PJe$J T)$, o processo de implantação iniciou em $2012^{45}$ e será finalizado em 2016, gerando significativa economicidade e celeridade processual. Para tanto,

\footnotetext{
${ }^{41}$ CALMON, Petrônio. Comentários a lei de informatização do processo judicial: Lei no 11.419 , de 19 de dezembro de 2006. 2. ed. Rio de Janeiro: Forense, 2008, p. 49.

${ }^{42}$ LEMOS, A. Cibercultura: tecnologia e vida social na cultura contemporânea. 5. ed. Porto Alegre: Sulina, 2010.

${ }^{43}$ BENUCCI, Renato Luis. A tecnologia aplicada ao processo judicial. Campinas: Millennium Editora, 2006, p.131.

${ }_{44}$ Até a data de 11.07.2015, havia o registro de 3.411,139 processos em tramitação pela plataforma do V2 na JF4R.

${ }^{45}$ Hoje, o PJe-JT funciona em 100 Varas do Trabalho e quatro Postos Avançados, abrangendo $75 \%$ das unidades de primeiro grau (no total, são 132 VTs e 10 Postos). O número de municípios que contam com o sistema chegou a 33 no ano passado, mais da metade daqueles que possuem sedes da Justiça Trabalhista no Rio Grande do Sul (65). A implantação iniciou em setembro de 2012. Na segunda instância, o PJe-JT já é operacionalizado por todas as Turmas Julgadoras e Seções Especializadas do TRT-RS.
} 


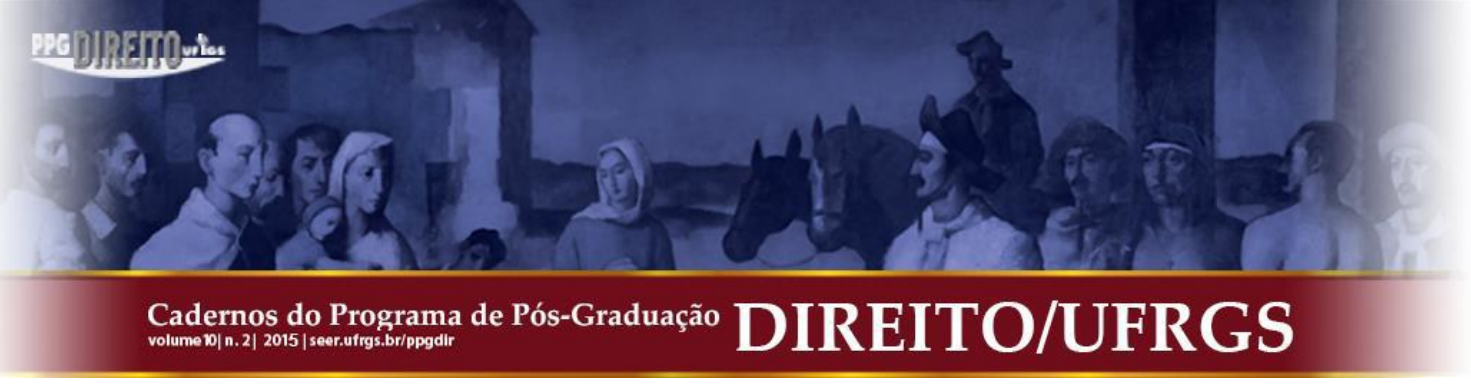

O processo eletrônico elimina o uso do papel, garante maior segurança e automatiza diversos atos processuais. A celeridade é uma das principais vantagens do sistema. Para os advogados, o PJe-JT diminui a necessidade de deslocamentos até as unidades judiciárias e possibilita o peticionamento via internet 24 horas por dia. A ferramenta também permite a consulta processual por login e senha, inclusive a partir de dispositivos móveis, como tablets e smartphones. ${ }^{46}$

A efetiva implementação do processo eletrônico na Justiça Estadual no Rio Grande do Sul traduzir-se-á numa ferramenta capaz de impor maior celeridade, economicidade, publicidade, efetividade, reduzindo-se, assim, o excessivo período que o processo permanece junto as Varas Estaduais aguardando as diligências.

O tempo do processo será demasiadamente modificado, enquanto no meio físico o expediente para protocolização encerar-se-á às $18 \mathrm{~h}$ (com vistas ao expediente adotado no Poder Judiciário Estadual), no meio virtual será às 23h59min, conforme preceitua a Lei 11.419/2006, que dispôs sobre a informatização do processo judicial.

Art. $3^{\circ}$ Consideram-se realizados os atos processuais por meio eletrônico no dia e hora do seu envio ao sistema do Poder Judiciário, do que deverá ser fornecido protocolo eletrônico.

Parágrafo único. Quando a petição eletrônica for enviada para atender prazo processual, serão consideradas tempestivas as transmitidas até as 24 (vinte e quatro) horas do seu último dia. ${ }^{47}$

Conforme ponderou o artigo $8^{\circ}$ da aludida Lei, aos órgãos do Poder Judiciário foram facultados o desenvolvimento de sistemas eletrônicos, capazes de acondicionar o processo eletrônico, de forma inteiramente virtual:

Os sistemas eletrônicos também deverão comportar as rotinas processuais como: procedimentos de distribuições, citações, intimações e notificações serão suportados pelo processo eletrônico. ${ }^{48}$

Em $1^{\circ}$ de junho de 2012, por meio do Ato da Presidência $n^{\circ}$ 016/2012-P, o Desembargador Marcelo Bandeira Pereira, na posição de Presidente do Tribunal de Justiça do Estado do Rio Grande do Sul, resolveu regulamentar o processo eletrônico (PJe) no âmbito do

46 TRT-RS altera cronograma de implantação do PJe-JT Disponível em:< 2015http://www.trt4.jus.br/portal/portal/trt4/comunicacao/noticia/info/NoticiaWindow?cod=1072300\&action=2>. Acesso em: 24 jun. 2015.

${ }^{47}$ BRASIL, (2006). Lei $n^{o} 11.419$, de 19 de dezembro de 2006. Dispõe sobre a informatização do processo judicial; altera a Lei no 5.869 , de 11 de janeiro de 1973 - Código de Processo Civil; e dá outras providências. Disponível em: < http://www.planalto.gov.br/ccivil_03/_ato2004-2006/2006/lei/111419.htm>. Acesso: 24 jun. 2015.

${ }^{48}$ Ibid.

Cadernos do Programa de Pós-Graduação em Direito PPGDir./UFRGS | Edição Digital | Porto Alegre | Volume X | Número 2 | 2015 | P. 364 - 390 


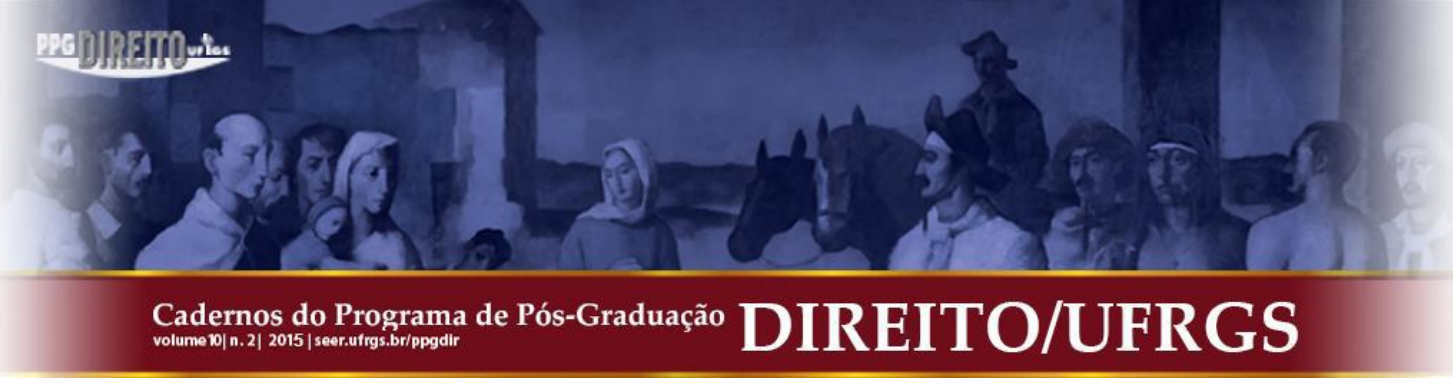

Poder Judiciário Estadual, estabelecendo que a implantação seria gradativa, iniciando-se a instituição nos Agravos de Instrumentos e Ações Originárias de $2^{\circ} \mathrm{Grau}$,

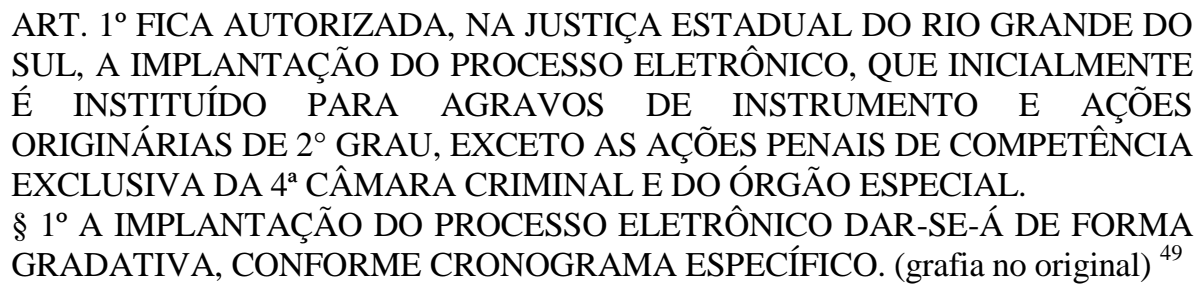

A responsabilidade do advogado, que antes se limitava a elaborar a Inicial e distribuí-la junto ao Setor de Distribuição, aumentou consideravelmente. No meio físico, a rotina processual, iniciava-se com o recebimento no Setor de Distribuição, lançamento no cadastro, fato que originava um número processual (utilizado em todos os atos), das partes. Após, direcionava-se à Vara selecionada, de acordo com a distribuição automática; e, assim, seguia para o Gabinete do Magistrado competente.

No meio virtual, o papel do advogado, como aduzido no parágrafo anterior, aumentou, de forma substancial, visto que se exige um cadastro ${ }^{50}$ prévio no Portal (também denominada plataforma), conversão de todos os documentos por meio do formato de documento portátil (PDF- Portable Documet Format) e, depois de promovidas tais diligências, far-se-á o cadastro das partes e a juntada dos documentos que comporão o processo, na forma eletrônica. Após o envio da petição, será emitido um protocolo, contendo todos os dados processuais. ${ }^{51}$

A responsabilidade do profissional (advogado) é reconhecidamente exacerbada, na medida em que, anteriormente a implementação, dirigia-se ao Setor de Distribuição e/ou Protocolo e retornava ao seu escritório profissional. Os prejuízos decorrentes eram a necessidade da mobilidade urbana, a morosidade na juntada e a análise a ser procedida pelo Magistrado competente.

Com a implantação do sistema eletrônico, os profissionais acessam do seu ambiente de trabalho (escritório profissional) ou de qualquer computador (conectado a internet), porém, em

\footnotetext{
${ }^{49}$ TRIBUNAL DE JUSTIÇA DO RIO GRANDE DO SUL. Ato $n^{\circ} 017 / 2012-P$, regulamenta o processo eletrônico no âmbito do poder judiciário estadual. Ano XIX nº 4.850. Data da disponibilização: 12 jun.2012. Porto Alegre: Diário da Justiça Eletrônico, 2012.

${ }^{50}$ Certificação digital, categoria A 3.

51 TRIBUNAL DE JUSTIÇA DO RIO GRANDE DO SUL. op. cit. Cadernos do Programa de Pós-Graduação em Direito PPGDir./UFRGS | Edição Digital | Porto Alegre | Volume X | Número 2 | 2015 | P. 364 - 390
} 


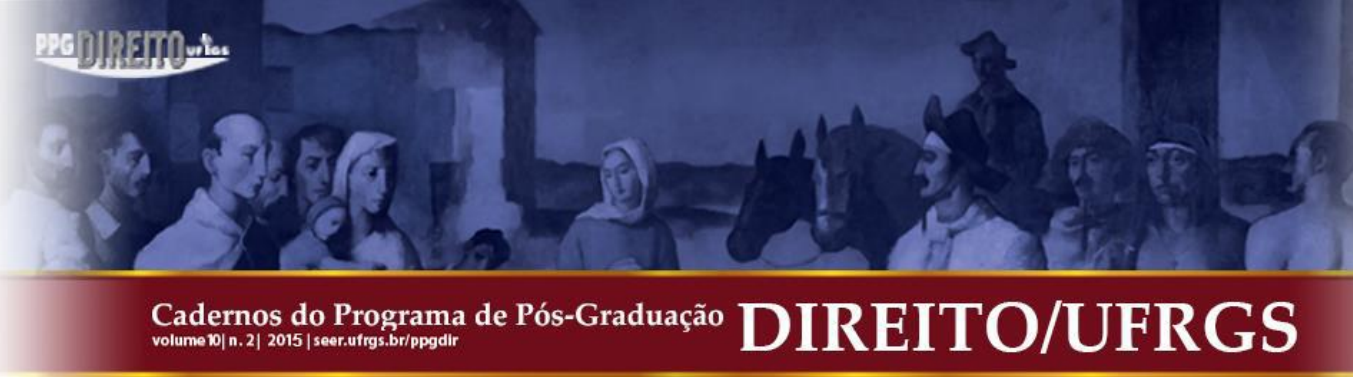

razão do sistema ser ininterrupto $(24 \mathrm{~h}),{ }^{52}$ os profissionais acabarão por aumentar a carga horária de trabalho, além dos encargos profissionais inerentes da advocacia.

Além da sobrecarga de horário decorrente, na mesma medida, houve uma sobrecarga em relação à responsabilidade na utilização do sistema, no momento da juntada dos documentos. Enquanto que pelo sistema físico, a juntada e numeração era incumbência dos serventuários, pelo sistema eletrônico a leitura que se dá é a substituição do termo "folha" por "evento" e, a juntada deve ser devidamente individualizada, sendo imputada uma penalidade caso seja descumprida tal exigência, assim:

\begin{abstract}
ART. $6^{\circ}$ INCUMBE AO USUÁRIO DO SISTEMA O CORRETO CADASTRAMENTO DOS DADOS SOLICITADOS NO FORMULÁRIO ELETRÔNICO, SENDO DE SUA RESPONSABILIDADE AS CONSEQUÊNCIAS DECORRENTES DO MAU PREENCHIMENTO DO FORMULÁRIO ELETRÔNICO E PERDA DE PRAZO PARA CONHECIMENTO DE MEDIDAS URGENTES, [...] (grafia no original) ${ }^{53}$
\end{abstract}

O processo eletrônico, inegavelmente, diminuirá o tempo morto do processo, na medida em que haverá severa redução das diligências- a saber- diminuição do encargo do distribuidor, eliminação do serventuário para perfurar e rubricar as folhas, assinatura manual, redução da necessidade de lançamento de notas de expedientes, deslocamento interno dos processos. Tais situações melhorarão o tempo do processo e, refletirão positivamente, em face da notória celeridade e economicidade processual.

De igual forma, tem-se o exemplo da prática processual junto a Justiça Federal, que, se por um lado, reduz o trabalho cartorial, em contrapartida, acrescenta as responsabilidades do advogado, o qual terá que ter um bom navegador de internet compatível com a necessidade da plataforma; cadastrar-se no Portal, converter em PDF, cadastrar as partes (autor e réu); requerer o benefício de assistência judicial ou imprimir as guias de custas judiciais; solicitar intervenção do Ministério Público, assinalar a incapacidade civil e/ou idoso; individualizar os documentos de acordo com o inciso IV do artigo $6^{\circ}$ da referida lei; conferir se todos os documentos encontram-se legíveis e, por fim, distribuí-la, recebendo o número do protocolo originado.

No cartório, o servidor acessará o processo eletrônico, verificando se o advogado cumpriu todos os requisitos extrínsecos e intrínsecos e, em caso positivo, direcionará ao Magistrado, para assim emitir o despacho eletrônico. Após, o advogado, obrigatoriamente,

\footnotetext{
52 Ibid.

${ }^{53}$ TRIBUNAL DE JUSTIÇA DO RIO GRANDE DO SUL. op. cit.

Cadernos do Programa de Pós-Graduação em Direito PPGDir./UFRGS | Edição Digital | Porto Alegre | Volume X | Número 2 | 2015 | P. 364 - 390
} 


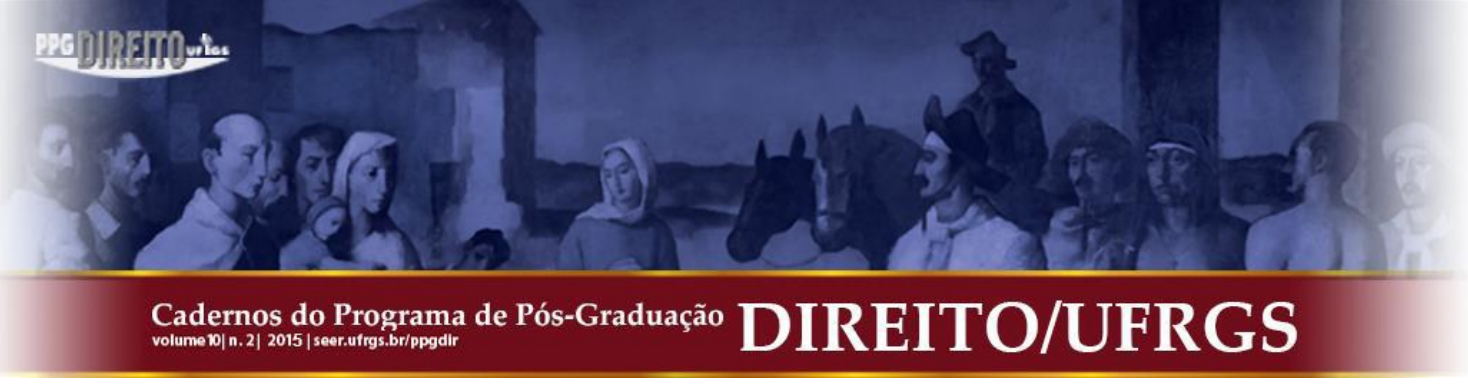

Para que o processo eletrônico seja viável em termos mínimos, quem se aventurar a utilizá-lo deve começar pelo cumprimento rigoroso das formalidades na sua composição, sob pena de inviabilizá-lo à outra parte e muito especialmente à atividade jurisdicional. E nem falo da baixa qualidade da imagem de muitos documentos, tornando impossível a leitura, e que são por isso considerados inexistentes por inacessibilidade do conteúdo, como já acontece com as fotocópias borrões no processo físico. [...] Na realidade, o Código já prevê a individualização dos documentos no processo físico, em especial os obrigatórios, o que os recorrentes em geral não cumprem, e o julgador às vezes tolera, levando em conta a singeleza do caso e a facilidade de encontrar as provas. Na essência, é o mesmo princípio da especificação das provas e de suas indicações nos arrazoados (CPC, art. 300), e que no contraponto obrigam ao julgador cumprir o art. 131. Já no eletrônico o cumprimento do princípio da individualização dos documentos é imprescindível, a fim de que o julgador saiba onde ver preenchidos os requisitos de admissibilidade e onde localizar a ratificação, ou não, das assertivas a respeito do bem da vida pretendido pelo recorrente, e, assim, formar a sua convicção.

[...] (Agravo de Instrumento $n^{\circ}$ 70065528093, Primeira Câmara Cível, Tribunal de Justiça do RS, Relator: Irineu Mariani, Julgado em 07/07/2015)

A crítica que o Relator Desembargador Irineu Mariani sopesou na sua decisão deve ser analisada com cautela, sob três óticas: 1) impossibilidade de substituição total do trabalhador, pois mesmo com o processo eletrônico, ainda haverá a pessoa, física e não eletrônica, do juiz, do escrivão, do escrevente, do distribuidor, do oficial, entre outros auxiliares; 2) sobrecarga de trabalho e responsabilidades dos profissionais da área jurídica e; 3) manutenção das instruções processuais, mantendo-se as audiências presenciais, o cumprimento dos Mandados, a realização das perícias técnicas, visando não ensejar o cerceamento da ampla defesa.

A simplificação do processo eletrônico como mera digitalização, evidenciará uma severa neutralidade dos direitos mínimos do indivíduo, o qual carece de condições, fomentadas pelo Estado e também pela Sociedade, para usar de forma adequada a rede mundial de tecnologia, sem privá-los da prestação jurisdicional efetiva, assegurando-se o equilíbrio entre o princípio democrático e a concepção substancial de justiça. ${ }^{54}$

A preocupação quanto ao exame restritivo acerca da mentalidade natural de expressar que o processo eletrônico resumidamente ao fator digitalização, também é uma apreensão tensionada pelos autores José Sebastião de Oliveira e Arlete Aparecida Chavenco, ao suscitarem que:

Ao estudar o processo eletrônico deve-se ter em mente que a digitalização de documentos não pode ser confundida com a ideia de processo eletrônico, pois este (processo eletrônico) é muito mais abrangente que aquela (digitalização). Implica uma

\footnotetext{
${ }^{54}$ APPIO, Eduardo. Controle judicial das políticas públicas no Brasil. Curitiba: Juruá, 2010, p. 25. Cadernos do Programa de Pós-Graduação em Direito PPGDir.JUfRGS | Edição Digital | Porto Alegre | Volume X | Número 2 | 2015 | P. 364 - 390
} 


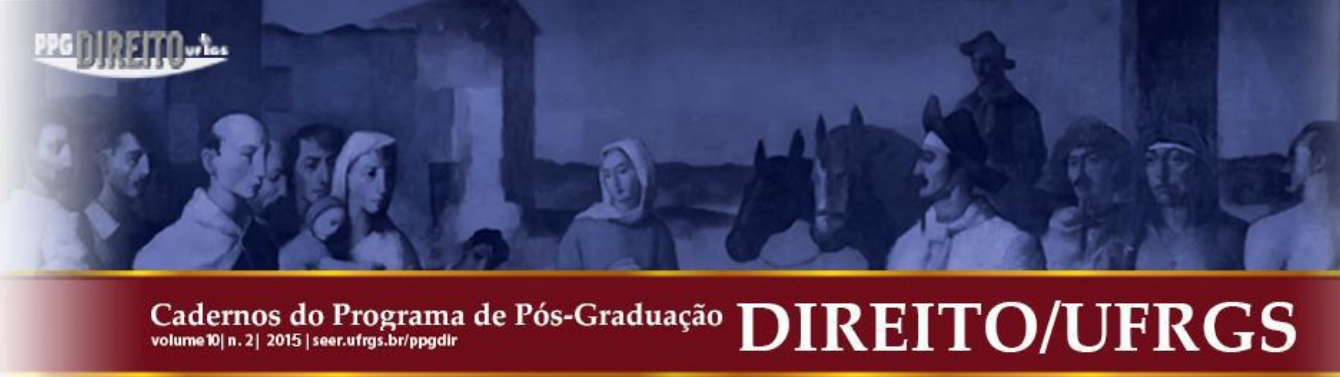

nova forma de proceder, uma verdadeira quebra de paradigmas e de rotinas tão arraigadas no Judiciário brasileiro. ${ }^{55}$

O processo eletrônico, assim, como é realizado pela Justiça Federal de forma integral, ou mesmo nas implantações dos projetos pilotos junto a Justiça do Trabalho, ou o peticionamento eletrônico do Superior Tribunal de Justiça e no Supremo Tribunal Federal representam economicidade e celeridade processual bem acentuada.

Entretanto, acredita-se que o cuidado que o Poder Judiciário carece ter, de forma permanente, é a manutenção dos direitos e garantias individuais, da proteção efetiva das partes, fornecendo-se uma instrução processual que coaduna com a necessidade do litígio e a resolução dos conflitos. Não olvidar que, por detrás das máquinas, encontram-se pessoas com anseios, desejos, sentimentos e emoções, que permanecerão ativas frente à atividade jurisdicional, visando à regularidade processual e um tratamento íntegro, mas que continuam sendo sujeitos que possuem limitações e juízos de valores, que não podem ser movidas e/ou impulsionadas por "click" ou removidas por um "delete".

\section{CONSIDERAÇÕES FINAIS}

Precipuamente, pretendeu-se examinar se a implementação do processo eletrônico no âmbito da justiça estadual como melhoria do tempo do processo, ensejando a prestação jurisdicional dentro de um tempo exequível. Tem-se que, se assegurado às prerrogativas e os princípios constitucionais, associados aos progressos na infraestrutura dos Cartórios e, do papel realizado pelos advogados, a efetivação do processo eletrônico poderá representar uma alternativa positiva.

No entanto, como o processo eletrônico ainda encontra-se em processo de implementação, muitos processos permanecem sendo ajuizados e tramitando pelo meio físico. Assim, o cenário continua difícil, com enormes estantes para acomodar os volumes dos processos, as mesas dos serventuários com pilhas capazes de "escondê-los" por detrás das mesas, além da precariedade nos recursos físicos e humanos que dilaceram o processo.

A prestação jurisdicional encontra severos entraves devido à burocracia instalada nos procedimentos e diligências realizadas no interior dos Cartórios das Comarcas que compõem o

55 OLIVEIRA, José Sebastião de; CHAVENCO, Arlete Aparecida. O processo eletrônico e a efetividade dos direitos fundamentais no contexto do acesso à justiça, p, 313. Disponível em: <http://revista.unicuritiba.edu.br/index.php/RevJur/article/viewFile/525/409>. Acesso em: 14 out. 2015.

Cadernos do Programa de Pós-Graduação em Direito PPGDir./UFRgS | Edição Digital | Porto Alegre | Volume X | Número 2 | 2015 | P. 364 -390 


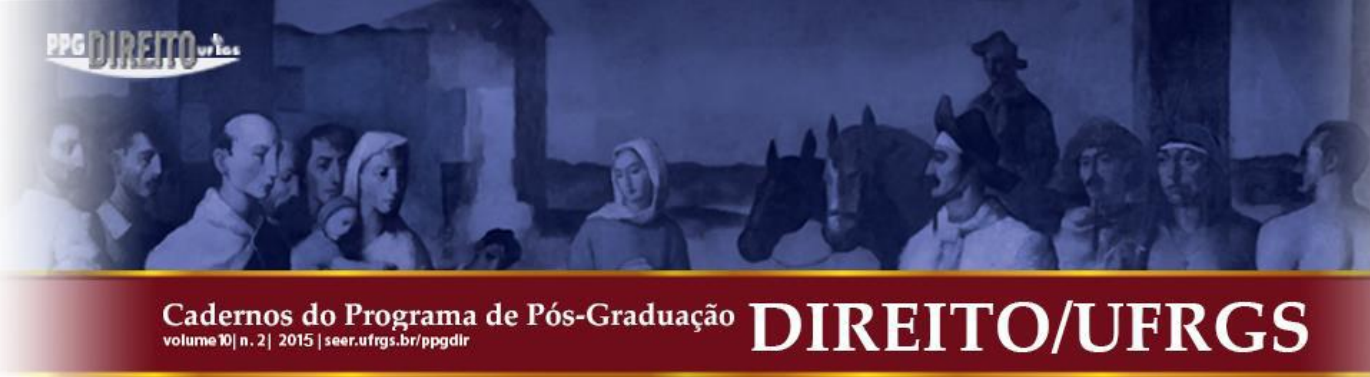

estadual seja efetivamente implementado, tendo alguns pormenores que deverão, contemporaneamente, serem tratados, em especial, em relação às rotinas cartoriais.

\section{REFERÊNCIAS}

AGÊNCIA Brasil. Clipping: Novo sistema pode reduzir em até $70 \%$ tempo de tramitação de processo na Justiça. Disponível em: <http://www.sindiregis.com.br/not.php?id=2275>. Acesso 24 jun. 2015.

ALEXY, Robert. Teoria dos direitos fundamentais. Tradução de Virgílio Afonso da Silva. 2. ed. São Paulo: Malheiros Editores, 2011.

APPIO, Eduardo. Controle judicial das políticas públicas no Brasil. Curitiba: Juruá, 2010.

ÁVILA, Humberto. Sistema constitucional tributário. São Paulo: Saraiva, 2004.

BENUCCI, Renato Luis. A tecnologia aplicada ao processo judicial. Campinas: Millennium Editora, 2006.

BRASIL. Decreto $n^{\circ}$ 678, de 06 de novembro de 1992. Promulga a Convenção Americana sobre Direitos Humanos (Pacto de São José da Costa Rica), de 22 de novembro de 1969. Disponível em: < http://www.planalto.gov.br/ccivil_03/decreto/D0678.htm>. Acesso em: 08 jul.2015.

BRASIL. Emenda Constitucional $n^{\circ} 45$, de 30 de dezembro de 2004. Altera dispositivos dos arts. $5^{\circ}, 36,52,92,93,95,98,99,102,103,104,105,107,109,111,112,114,115,125,126$, 127, 128, 129, 134 e 168 da Constituição Federal, e acrescenta os arts. 103-A, 103B, 111-A e 130-A, e dá outras providências. Disponível em: < http://www.planalto.gov.br/ccivil_03/constituicao/Emendas/Emc/emc45.htm>. Acesso em: 06 jul. 2015.

BRASIL. Constituição da República Federativa do Brasil de 1988. Disponível em:< http://www.planalto.gov.br/ccivil_03/constituicao/constituicaocompilado.htm>. Acesso em: 24 jun. 2015.

BRASIL. Lei $n^{\circ} 11.419$, de 19 de dezembro de 2006. Dispõe sobre a informatização do processo judicial; altera a Lei $n^{0}$ 5.869, de 11 de janeiro de 1973 - Código de Processo Civil; e dá outras 


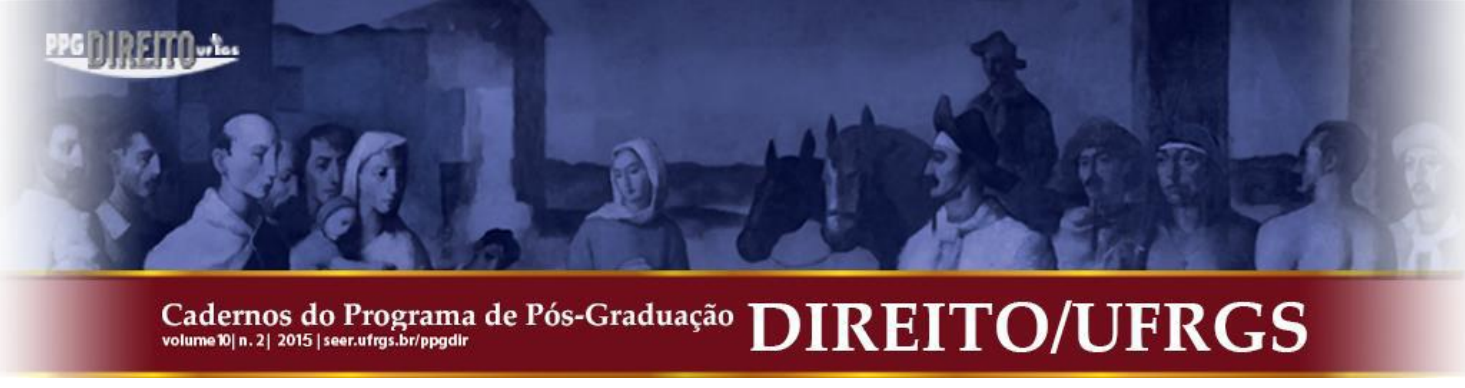

LEAL, Rogério Gesta. Impactos da corrupção no direito fundamental a uma prestação jurisdicional conforme a justiça constitucional. In: COSTA, Marli Marlene Moraes da; LEAL, Mônia Clarissa Hennig. (Org.) Direitos sociais e políticas públicas. Desafios contemporâneos. Tomo 14. Santa Cruz do Sul, EDUNISC,2014.

LEAL, Rogério Gesta. Patologias corruptivas nas relações entre estado, administração pública e sociedade: causas, consequências, e tratamento. Santa Cruz do Sul: EDUNISC, 2013.

LEMOS, A. Cibercultura: tecnologia e vida social na cultura contemporânea. 5. ed. Porto Alegre: Sulina, 2010.

MILBRADT, Patrícia Amaral. A efetividade do acesso à justiça por meio do processo eletrônico. Monografia apresentada no curso de graduação da Universidade Federal do Rio Grande do Sul, 2010. Disponível em: <https://www.lume.ufrgs.br/bitstream/handle/10183/27084/000763586.pdf?sequence=1 .> Acesso em: 12 out.2015.

OLIVEIRA, José Sebastião de; CHAVENCO, Arlete Aparecida. O processo eletrônico e a efetividade dos direitos fundamentais no contexto do acesso à justiça. Disponível em: <http://revista.unicuritiba.edu.br/index.php/RevJur/article/viewFile/525/409>. Acesso em: 14 out. 2015 .

OST, François. O tempo do direito. Tradução de Maria Fernanda Oliveira. Lisboa: Instituto Piaget, 1999.

RESTA, Eligio. Tempo e processo. Tradução de Fabiana Marion Spengler. Santa Cruz do Sul: Essere Nel Mondo, 2014.

ROSA, Alexandre Morais da; MARCELLINO JR, Julio Cesar. O (re)pensar da crise jurisdicional diante do engodo eficientista: o direito e a economia em discussão. In: SPENGLER, Fabiana Marion; BRANDÃO, Paulo de Tardo. Os (des)caminhos da jurisdição. Florianópolis: Conceito Editorial, 2009.

RUBIO, David Sanchez; FLORES, Joaquim Herrera; CARVALHO, Salo de (Orgs.). Direitos Humanos e globalização: fundamentos e possibilidades desde a teoria crítica. Anuário Iberoamericano de Direitos Humanos (2003/2004). 2. ed. Porto Alegre: EDIPUCRS, 2010. p.1109. Disponível em: <http://www.pucrs.br/edipucrs/direitoshumanos.pdf>. Acesso em: 12 set.2015. 


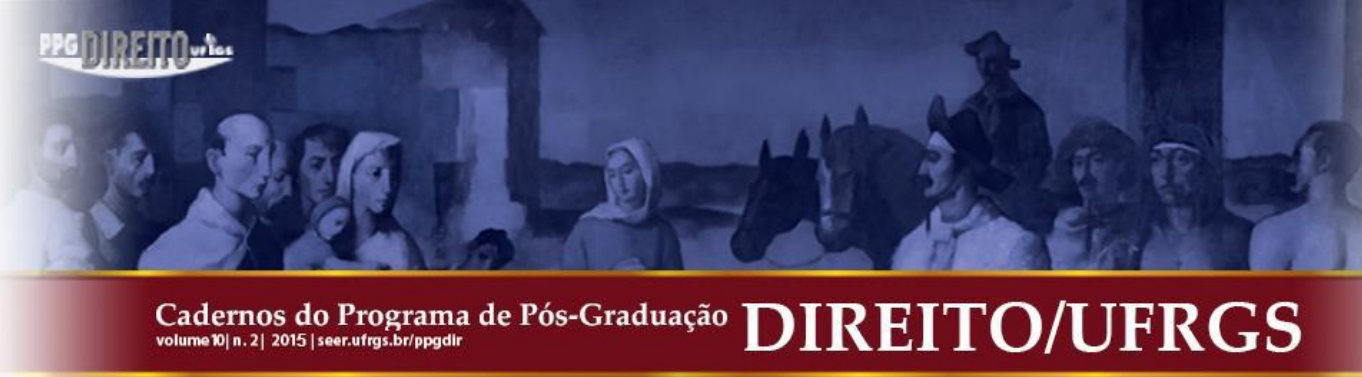

SANTOS, Boaventura de Sousa. Para uma revolução democrática da justiça. 3. ed. São Paulo: Cortez, 2011.

SOVERAL, Raquel Tomé. MIGLIAVACCA, Luciano de Araújo. Reforma do Código de processo civil: a busca pela razoável duração do processo, como direito fundamental, frente às garantias processuais. Disponível em: <https://seer.imed.edu.br/index.php/revistadedireito/index>. Acesso em: 24 out.2015.

SPENGLER, Fabiana Marion. Tempo, direito e Constituição: reflexos na prestação jurisdicional do Estado. Porto Alegre: Do Advogado, 2008.

SPENGLER, Fabiana Marion. Tempo, direito, processo e narrativa: outra abordagem do conflito social. In: COSTA, Marli Marlene Moraes da; LEAL, Mônia Clarissa Hennig. (Org.) Direitos sociais e políticas públicas. Desafios contemporâneos. Tomo 14. Santa Cruz do Sul: EDUNISC, 2014.

TRIBUNAL DE JUSTIÇA DO RIO GRANDE DO SUL. Ato $n^{\circ} 017 / 2012-P$, regulamenta o processo eletrônico no âmbito do poder judiciário estadual. Ano XIX $n^{\circ} 4.850$. Data da disponibilização: 12 jun.2012. Porto Alegre: Diário da Justiça Eletrônico, 2012.

TRIBUNAL DE JUSTIÇA DO RIO GRANDE DO SUL. TRT-RS altera cronograma de implantação do PJe-JT $\quad$ Disponível em:< 2015http://www.trt4.jus.br/portal/portal/trt4/comunicacao/noticia/info/NoticiaWindow?cod=10 72300\&action=2> . Acesso em: 24 jun. 2015.

TUCCI, José Rogério Cruz e. Tempo e processo. São Paulo: Revista dos Tribunais, 1998.

WEBER, M. Economia e sociedade. Brasília: UNB, 1999.

Submissão: 28/09/2015

Aceito para Publicação: 26/10/2015 
MDIRIThutes

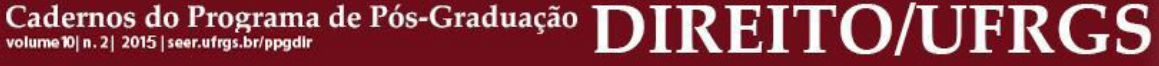

